\title{
Towards a European Nationality Law-Vers un droit européen de nationalité
}

Citation for published version (APA):

de Groot, G. R. (2003). Towards a European Nationality Law-Vers un droit européen de nationalité. unigraphic, Universiteit Maastricht. https://doi.org/10.26481/spe.20031113gg

Document status and date:

Published: 13/11/2003

DOI:

10.26481/spe.20031113gg

Document Version:

Publisher's PDF, also known as Version of record

\section{Please check the document version of this publication:}

- A submitted manuscript is the version of the article upon submission and before peer-review. There can be important differences between the submitted version and the official published version of record.

People interested in the research are advised to contact the author for the final version of the publication, or visit the DOI to the publisher's website.

- The final author version and the galley proof are versions of the publication after peer review.

- The final published version features the final layout of the paper including the volume, issue and page numbers.

Link to publication

\footnotetext{
General rights rights.

- You may freely distribute the URL identifying the publication in the public portal. please follow below link for the End User Agreement:

www.umlib.nl/taverne-license

Take down policy

If you believe that this document breaches copyright please contact us at:

repository@maastrichtuniversity.nl

providing details and we will investigate your claim.
}

Copyright and moral rights for the publications made accessible in the public portal are retained by the authors and/or other copyright owners and it is a condition of accessing publications that users recognise and abide by the legal requirements associated with these

- Users may download and print one copy of any publication from the public portal for the purpose of private study or research.

- You may not further distribute the material or use it for any profit-making activity or commercial gain

If the publication is distributed under the terms of Article $25 \mathrm{fa}$ of the Dutch Copyright Act, indicated by the "Taverne" license above, 
Towards a

European Nationality Law -

Vers un droit européen de nationalité 


\section{Colofon}

Basisontwerp en realisatie: Unigraphic, Universiteit Maastricht

ISBN $x x-x x x x-x x x-x$

Alle rechten voorbehouden. Niets uit deze uitgave mag worden verveelvoudigd, opgeslagen in een geautomatiseerd gegevensbestand of openbaar gemaakt, zonder voorafgaande schriftelijke toestemming van de auteur of uitgever. 


\section{Towards a}

European Nationality Law -

Vers un droit européen de nationalité

Inaugural lecture

delivered on 13 November 2003

on the occasion of the acceptance of

the Pierre Harmel chair of

professeur invité at the Université de Liège

Prof. Dr. Gerard-René de Groot

U

M Universiteit Maastricht 


\section{Introduction 1}

Article 8 (1) of the Draft Treaty establishing a constitution for Europe ${ }^{2}$ prepared by the European convention chaired by Valéry Giscard d'Éstaing provides as follows:

'Every national of a Member State shall be a citizen of the Union. Citizenship of the Union shall be additional to national citizenship; it shall not replace it.'

This provision of the Draft Constitution repeats, in slightly different wording, Article 17 (1) EC (introduced in 1992 by the Treaty of Maastricht on the European Union3.4):

'1. Citizenship of the Union is hereby established. Every person holding the nationality of a Member State shall be a citizen of the Union.'

And since the Treaty of Amsterdam5 Article 17 continues as follows:

'Citizenship of the Union shall complement and not replace national citizenship.'

Several questions arise in respect of these provisions. The core part of this inaugural lecture will deal with the question as to whether the introduction of European citizenship has consequences for the autonomy of the Member States in matters of nationality. However, before going into this, I would like to briefly dwell on two other issues:

1) the precise relationship between the terms "nationality" and "citizenship" and 2) the statement, which is incorrect, that all nationals of a Member State are European citizens, as expressed in these provisions.

1 A word of thanks is in order to Louise Rayar for her English revision work.

2 As submitted to the President of the European Council in Rome on 20 July 2003, OJ C 169 of 18 July 2003.

3 OJ C 224 of 31 August 1992. See i.a. Closa, CMLR 1992, 1137-1169; Closa 1994, 109-120; Closa, CMLR 1995, 497-518; Evans, ELR 1991, 190-215; Evans/ Jessurun d'Oliveira 1991; Evans 1995, 85-112; Jessurun d'Oliveira 1994, 126-148; Jessurun d'Oliveira 1995, 58-84; Kojanec 1998, 133-138; Lippolis 1994; Pérez Vera 1993. 1123-1147; Preuss 1995, 267-281; Sauerwald 1996.

4 Effective as of 1 November 1993. Before the Treaty of Amsterdam came into force, Article 17 used to be Article 8.

5 OJ C 340 of 10 November 1997, in force since 1 May 1999. 


\section{Terminology}

First of all, the terminology of Article 8 (1) Draft Constitution and Article 17 EC Treaty is remarkable. In the English text, two different terms are used: "nationality"6 and "citizenship". The relationship between these two concepts expressed in the English language is not fully clear. In the United Kingdom, the term "nationality" is used to indicate the formal link between a person and the state. The statute that regulates this status is the British Nationality Act.7 The most privileged status to be acquired under this Act, however, is the status of "British citizen". 8 In Ireland, it is the Irish Nationality and Citizenship Act9 that regulates who precisely possess Irish citizenship. In the United States, the Immigration and Nationality Act ${ }^{10}$ regulates who is an American citizen, but the Act also provides that the inhabitants of American Samoa and Swains Island have the status of American national without citizenship. ${ }^{11}$

In the context of the EC Treaty and the Draft Constitution, however, it is obvious that "nationality" refers to the formal link between a person and a state, irrespective of how this link is called under national law, whereas "citizenship of the Union" refers to the newly created status in Community law. In the sentence added to Article 17 EC by the Treaty of Amsterdam, "national citizenship" is most probably to refer to possession and exercise of 'citizenship rights' at national level. It fails to explain what precisely is meant by "national citizenship". Remarkable

6 The Draft Constitution uses the expression 'Every national' instead of 'Every person holding the nationality'.

7 Enacted in 1981, in force since 1 January 1983. See also BNA (Commencement) Order 1982,Statutory Instruments 1982, 933. The BNA 1981 has been amended on several occasions, most recently by the Nationality, Immigration and Asylum Act 2002.

8 Other status are: British Overseas Territories Citizen (SS. 15-25 BNA 1981, amended in 2002 by the British Overseas Territories Act 2002), British Overseas Citizen (SS. 26-29 BNA 1981), British Subject without Citizenship (SS. 30-32 BNA 1981) and British Protected Persons (SS. 38 and 50 (1) BNA 1981).

9 Act of the Oireachtas 1956, 439 (most recently amended by the Irish Nationality and Citizenship Act 2001 (Act. 15/2001 of 5 June 2001).

10 Act of 27 June 1952, Pub.L 82 414, 66 Stat. 163, as amended, codified in 8 U.S.C., Sec. $1101 \mathrm{ff}$.

11 Immigration and Nationality Act 1952, Section 308 (8 U.S.C. 1408) regarding persons born in an outlying possession of the United States. 
also is that Article 17 EC provides that citizenship of the Union 'shall complement' national citizenship, whereas Article 8 (1) Draft Constitution prescribes that it 'shall be additional.' The question needs to be raised as to whether the word 'additional' was chosen to indicate that nationality (of a Member State) is to be the primary status of a person and citizenship of the Union a secondary, accessory status. The word 'complement' places both notions almost at the same level and seems to be a better word, seeing that citizenship of the Union is considered 'destined to be the fundamental status of nationals of the Member States.'12

It is very interesting to study the different language versions of the EC Treaty and the Draft Constitution. As the English version, five other language versions also use two different terms in Article 17 EC to denote the concepts of "nationality" and "citizenship". This is, for example, the case in the French version, where the words "nationalité" and "citoyenneté"13 are used.

See furthermore:

Dutch: nationaliteit-burgerschap;

German: Staatsangehörigkeit'14-Bürgerschaft'15;

Portugese: nacionalidade-cidadania;

Spanish: nacionalidad-ciudadania

In four of these languages, the term for the formal link between a person and the state is evidently related etymologically to the English "nationality". In the German language, the word "Staatsangehörigkeit"

12 ECJ 2 October 2003 (Case C-148/O2), Nr. 26, in re: Garcia Avello.

13 See on the relationship between these two French concepts throughout history: Guiguet 1997; also: Guiguet 1998, in La Torre, 95-111; Verwilghen 1999, 77 $\mathrm{ff}$.

14 In Austria "Staatsangehörigkeit" is called "Staatsbürgerschaft"; from an Austrian perspective, therefore, European "Bürgerschaft" is acquired through Austrian "Staatsbürgerschaft". Compare the title of the Austrian Nationality Act: Staatsbürgerschaftsgesetz (Act of 15 July1965, Bundesgesetzblatt 1965, 68). Compare the title of the Austrian Nationality Act: Staatsbürgerschaftsgesetz (Act of 15 July 1965, Bundesgesetzblatt 1965, 68).

15 The German word "Nationalität" is avoided because of its obvious ethnic dimension. 
indicates that a person belongs ('gehört', in German:) to a state (German: "Staat").

In French, Portuguese and Spanish, the terms denoting "citizenship" (citoyen, cidadão, ciudadano) are closely related etymologically to the English language, which uses "citizen" and "city" (cité, cidade, ciudad). The Dutch and German terms are "burger" and "Bürger", respectively. Originally, the term was used to denote a person living in a fortified city. ${ }^{16}$

In the Greek version, as many as three different terms are used:

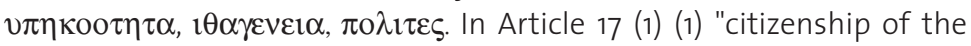

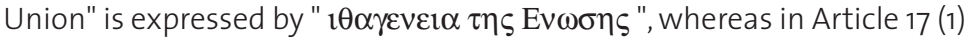

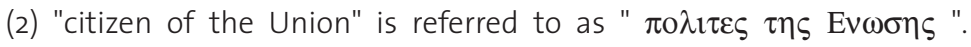
National citizenship is referred to as " $\varepsilon \theta v i \kappa \eta ~ \imath \theta \alpha \gamma \varepsilon v \varepsilon 1 \alpha$ ", which could be slightly problematic because of the use of the adjective " $\varepsilon \theta v i \kappa \eta "$ ". In the Greek version of Article 17, "Nationality of a Member State" is expressed by " is no longer used; instead, again the expression " $\varepsilon \theta v i \kappa \eta ~ \imath \theta \alpha \gamma \varepsilon v \varepsilon \imath \alpha$ " is used.

In four other languages of the Union, a single term is used to denote the concepts of "nationality" and "citizenship". The Italian version uses "cittadinanza" for both. The Italian word "nazionalità" could not be used because of its obvious ethnic connotation. The Danish text refers to "statsborger i en medlemsstat" and "unionsborgerskab", thus referring twice to "borgerskab". The Danish word "nationalitet" had to be avoided, also because of its "ethnic" connotation.

\section{Compare:}

Finnish: kansalainen-kansalaisuus;

Swedish: medborgare i en medlemsstat-unionsmedborgare

In almost all the languages of the candidate Member States, which will join the European Union on 1 May 2004, a single word is used in the text of Article 8 Draft Constitution:

Estonian: kdanik-kodakondsus;

Latvian: pilsonis-pilsoniba;

16 Kotalakidis, 45; Vink 23, 24. Compare: borough, bourge, $\pi v \rho \gamma o \varsigma$ 
Lithuanian: pilietybe-Sajungos pilietybie;

Hungarian: polgarsag-allampolgarsagot;

Maltese: cittadinanza-cittadinanza ta'l-Unjoni;

Polish: obywatelstwa-obywatelstwo;

Slovak: statnemu obcianstvu-obcianstvo únie;

Slovenian: drzavljanstva-drzavljanstvo Unije.

A problem in nearly all of these languages was how to avoid words that referred to the ethnic dimension of persons. Only in the Czechlanguage version, two different words are used: státni prislusnostobcanstvi Unie, which more or less have the same relationship as Staatsangehörigkeit and Staatsbürgerschaft in the German language. ${ }^{17}$

It is remarkable that the Danish text does not use the Danish word "indfødsret" for "nationality", whereas the Danish Nationality Act ${ }^{18}$ does. The dual use of the word "borgerskab" in the Danish version may perhaps partly explain the Danish fear that the creation of European citizenship could be the first step towards the decline of their own (Danish) nationality. Compare the Danish declaration on citizenship of the Union on the occasion of the Danish ratification of the Maastricht Treaty 19 :

'1. Citizenship of the Union is a political and legal concept that is entirely different from the concept of citizenship within the meaning of the Constitution of the Kingdom of Denmark and of the Danish legal system. Nothing in the Treaty on European Union implies or foresees an undertaking to create a citizenship of the Union in the sense of citizenship of a nation-State. The question of Denmark participating in any such development does, therefore, not arise.

2. Citizenship of the Union in no way in itself gives a national of another Member State the right to obtain Danish citizenship or any of the rights, duties, privileges or advantages that are inherent in Danish citizenship by virtue of Denmark's constitutional, legal and administrative rules. Denmark will fully respect all specific rights expressly provided for in the Treaty and applying to nationals of the Member States ....'

17 Information by Lucas Bortel in an E-mail message of 8 October 2003.

18 Lov om dansk indf $\varnothing$ dsret.

19 OJ 1992, C 348/1. 
In reaction to this Danish statement, the Heads of State or Government20 in the European Council session of 11 and 12 December 1992 reiterated the message contained in the declaration on nationality attached to the Maastricht Treaty:

'The provisions, of Part Two of the Treaty establishing the European Community relating to citizenship of the Union give nationals of the Member States additional rights and protection as specified in that Part. They do not in any way take the place of national citizenship. The question whether an individual possesses the nationality of a Member State will be settled solely by reference to the national law of the Member State concerned.'

Danish hesitation ultimately led to amendment of Article 17 EC by the Amsterdam Treaty, in which it was emphasised that citizenship of the Union complemented rather than replaced national citizenship.

It is noteworthy that, although the Italian text, like the Danish, uses both times the same expression ("cittadinanza"), Italian authorities and scholarly writers did not have the same reservations as the Danish. ${ }^{21}$ This may, perhaps, be explained by a difference in approach by Denmark and Italy in respect of Drafts published by the European Commission.

Denmark has always been very critical (as has been the United Kingdom) where details in the text of the drafts are concerned, whereas Italy tends to concentrate on the gist of a proposal, without paying too much attention to detail. Furthermore, in Danish, a second word, "indfødsret", was available, whereas in the Italian language, to the best of my knowledge, there was not.

20 Decision of the heads of state or government, meeting within the European Council, concerning certain problems raised by Denmark on the Treaty on European Union (see Official Journal 1992 C 348/1). See on this decision Curtin/Van Ooik, in: O'Keeffe/Twomey, 349-365.

21 It should be noted that at the time of signature of the Maastricht Treaty Finland and Sweden were not yet Member States of the Union. 


\section{Not All Nationals of a Member State are European Citizens}

In spite of the clear statement of Article 17 EC and Article 8 Draft Constitution that every national of a Member State is a citizen of the Union, it can be observed that some nationals of Member States do not have this status. This is in particular the case in the United Kingdom.

Already at the occasion of its accession to the EC in 1972, the United Kingdom issued a special declaration ${ }^{22}$ defining who is British for Community purposes:

'As to the United Kingdom of Great Britain and Northern Ireland, the terms "nationals", "nationals of Member States" or "nationals of Member States and overseas countries and territories" wherever used in the Treaty establishing the European Economic Community, the Treaty establishing the European Atomic Energy Community or the Treaty establishing the European Coal and Steel Community or in any of the Community acts deriving from those Treaties, are to be understood to refer to:

persons who are citizens of the United Kingdom and Colonies or British subjects not possessing that citizenship or the citizenship of any other Commonwealth country or territory, who, in either case, have the right of abode in the United Kingdom, and are therefore exempt from United Kingdom immigration control;

persons who are citizens of the United Kingdom an Colonies by birth or by registration or naturalisation in Gibraltar, or whose father was so born, registered or naturalised.'

This declaration was replaced by another in 1981.23 This was necessary, because the rules on British nationality had been completely overhauled by the British Nationality Act 1981, which came into effect on 1 January $1983^{24}$ :

See Official Journal (EC) 1972 L 73/196; BGBI. II, 1410; on this declaration: Evans, YEL 1982, 174-189; Evans, AJCL 1984, 679-715; Plender, in: Jacobs (ed.), 42-45. Compare also Command Paper 9062, and Jessurun d'Oliveira 1999, in: O'Keeffe/Twomey (eds.), 400, 401.

Official Journal 1983, C 23/1.

24 See Bonner, ELR 1982, 69 ff.; Evans, SLT 1981, 133-137; Evans, MLR 1982, 497-515; De Groot 1989, 103; Simmonds, CMLR 1984, 675-686. 
'As to the United Kingdom of Great Britain and Northern Ireland, the terms "nationals", "nationals of Member States" or "nationals of Member States and overseas countries and territories" wherever used in the Treaty establishing the European Economic Community, the Treaty establishing the European Atomic Energy Community or the Treaty establishing the European Coal and Steel Community or in any of the Community acts deriving from those Treaties, are to be understood to refer to:

British citizens;

Persons who are British subjects by virtue of Part IV of the British Nationality Act 198125 and who have the right of abode in the United Kingdom and are therefore exempt from United Kingdom immigration control; British Dependent Territories citizens who [have acquired] their citizenship from a connection with Gibraltar.

The reference in Article 6 of the third Protocol to the Act of Accession of 22 January 1972, concerning the Channel Islands ${ }^{26}$ and the Isle of Man27, to "any citizen of the United Kingdom and Colonies" is to be understood as referring to "any British citizen".'

Because of these declarations, some categories of British nationals, in particular most 'British Dependent Territories Citizens', 'British Overseas Citizens', 'British Subjects without Citizenship' and 'British Protected Persons' 28 are excluded from European citizenship. One of these categories, the 'British Dependent Territories Citizens', merits some additional remarks. The 'British Dependent Territories' were renamed 'British Overseas Territories' by Section 1 of the British Overseas Territories Act 2002, which received Royal Assent on 26 February 2002. Under Section 1, British Dependent Territories Citizenship was renamed 'British Overseas Territories Citizenship'. From then on, "British Dependent Territories Citizen" in the 1981 British declaration must be read as "British Overseas Territories Citizen". However, the British Overseas Territories Act 2002 produced yet another, even more important, modification:

25 I.e.: British subjects without citizenship.

26 On the Channel Islanders: De Groot, in: Müller-Graf 2002, 70; Juárez Peréz, 170, 171.

27 On the Manxmen: De Groot, in: Müller-Graf 2002, 70; Juárez Peréz, 170, 171.

28 See on these different categories of British nationals: De Groot 1989, 103, with further references on p. 408. 
Section 3 of the Act provides as follows:

'Any person who, immediately before the commencement of this section, is a British overseas territories citizen shall, on the commencement of this section, become a British citizen.'

The day of commencement was fixed at 21 May 2002. ${ }^{29}$ In respect of the formulation of the 1981 British declaration, it can be concluded that former British Dependent Territories Citizens, who became British Overseas Territories Citizens by Royal Assent on 26 February 2002, on 21 May 2002 also received European citizenship through having been granted British citizenship. 30 However, there is one exception: British citizenship was not extended to persons who after 26 February 2002 were British Overseas Territories Citizens by virtue of a connection with the Sovereign Base Areas of Akrotiri and Dhekelia. ${ }^{11}$

These base areas, located on the island of Cyprus, are British Overseas Territories, but extending British citizenship was deemed to be inappropriate, because of the military nature of these British possessions. For this reason, these British Overseas Territories Citizens do not possess British citizenship and are therefore definitely not European citizens.

Furthermore, it must be borne in mind that British citizenship is conferred to the other British Overseas Territories Citizens in addition to the status they possess. The consequence of this is that the persons in question may issue a declaration of renunciation in order to divest themselves of British citizenship. If this happens, they are exclusively British Overseas Territories Citizens, not possessing European citizenship, of course.

These legal constructions show that the status of "British Overseas Territories Citizen" has not been abolished: furthermore, acquisition of this status on the basis of the provisions of the amended British

29 See British Overseas Territories Act 2002 (Commencement) Order 2002, S. 2 (a).

30 The number of persons involved is approx. 200,000, living in thirteen British overseas territories: Anguilla, Bermuda, British Antarctic Territory, British Indian Ocean Territory, British Virgin Islands, Cayman Islands, Falkland Islands, Gibraltar, Montserrat, Pitcairn Islands, St Helena and Dependencies, South Georgia and the South Sandwich Islands, and the Turks and Caicos Islands.

31 Both base areas are located in the south of the island of Cyprus. 
Nationality Act does not result in acquisition of British citizenship. Persons who have acquired British Overseas Territories Citizenship after 21 May 2002 can only apply to be registered as British citizens. Registration is at the discretion of the Secretary of State.32.33

In respect of all these changes concerning British Dependent Territories Citizens, it can be concluded that the United Kingdom must review the 1981 declaration. It is not the British Dependent Territories Citizens, but some British Overseas Territories Citizens (and some other categories such as British Overseas Citizens) who are now excluded. Furthermore, it is useful to know whether the United Kingdom will preserve the statement that, for Community purposes, all British citizens are British, including those living in British Overseas Territories.

The validity of the exclusion of certain British nationals from European citizenship was challenged before the European Court of Justice in 2001 in the Manjit Kaur Case.34 Manjit Kaur was a British Overseas Citizen (not: a British Overseas Territories Citizen!) of Indian extraction, who lived in East Africa. She argued that the British declaration deprived her of European citizenship. The European Court of Justice concluded that she was not deprived of European citizenship, because she had never been a European citizen, according to the British declaration:

'Furthermore, adoption of that declaration did not have the effect of depriving any person who did not satisfy the definition of a national of the United Kingdom of rights to which that person might be entitled under Community law. The consequence was rather that such rights never arose in the first place for such a person.'

Furthermore, the Court stressed that the British declaration was in conformity with the special "Declaration (no 2) on nationality of a Member State", which is attached to the Maastricht Treaty.

32 S. $4 A$ BNA 1981, as amended by the British Overseas Territories Act 2002: '...the Secretary of State may if he thinks fit cause the person to be so registered.'

33 Another category of British Overseas Territories Citizens without British citizenship are the llois covered by S. 6 (3) of the British Overseas Territories Act 2002.

34 ECJ 20 February 2001, Case 192/99, ECR I-1237. 
The Declaration reads as follows:

'The Conference declares that, wherever in the Treaty establishing the European Community reference is made to nationals of the Member States, the question whether an individual possesses the nationality of a Member State shall be settled solely by reference to the national law of the Member State concerned. Member States may declare, for information, who are to be considered their nationals for Community purposes by way of a declaration lodged with the Presidency and may amend any such declaration when necessary.'

Apart from the United Kingdom, only one other Member State issued a declaration on the definition of nationals for Community purposes. As far back as 1957, Germany declared that not only Germans within the meaning of the German Nationality Act (Reichs- und Staatsangehörigkeitsgesetz 1913, with amendments) -which already included all nationals of the Democratic Republic of Germany- must be regarded as Germans for European Community purposes, but also Germans within the meaning of Article 116 German Constitution (Grundgesetz), including ethnic Germans in Eastern Europe, for instance the "Wolga-Germans", if they had entered Germany as refugees (Vertriebene). 35

However, since 1 January 2000, this German declaration is no longer of practical relevance, because from this date onwards anyone recognised as a German within the meaning of Article 116 German Constitution simultaneously acquires German nationality ex lege on the basis of the revised German Nationality Act. 36

Nevertheless, there are several other categories of nationals of Member States, with regard to whom it is doubtful whether they possess European citizenship. I do not intend to elaborate on these in this

35 See Treaties establishing the European Communities, Office for Official Publications of the European Communities 1978, 573. Compare Bleckmann, CMLR 1978, 435-446 and Bleckmann, CMLR 1980, 467-485. Furthermore: De Groot, Publiek Domein 1990, 2-6; Jessurun d'Oliveira 1999, in: O'Keeffe/ Twomey, 400 .

36 Article 7 of the German Nationality Act, as amended by Act of 15 July 1999, Bundesgesetzblatt 1999 I, 1618. See also the transitional provision of Article $40 a$. 
lecture, but only wish to highlight some of the interesting borderline categories of European citizenship.37 In spite of their Danish nationality, the Danish inhabitants of the Faroe Islands 38 are not European citizens. However, with regard to the Danish Greenlanders39, the Netherlands Antillians, the Arubans 40 and the French inhabitants of French overseas territories (territoires outremer), it must be concluded -after some hesitation- that they do possess European citizenship41, although they reside within territories of the Member States, which are not situated within the territory of the European Union. Of interest as well is the position of those Spanish nationals, who, in addition to their Spanish nationality, possess the nationality of a Latin-American country pursuant to the Treaties on dual nationality, which Spain entered into with 12 different Latin-American countries. 42

If residing in Spain, they are definitely European citizens. If they are living in Latin America, or a third State, European citizenship depends on whether they are entitled to a Spanish passport. In the original versions of the different Treaties on dual nationality, they were not entitled to a Spanish passport, but recent amendments to several treaties grant this right, even to those residing in Latin America. If they hold a Spanish passport, they can present 43 themselves as European citizens. 44

Remarkable also is the position of the (descendants) of dual ItalianArgentinean citizens, due to the Italian-Argentinean treaty on dual

37 See for details: De Groot, FS Bleckmann 1993, 87-103; De Groot, in: La Torre 1998, 115-147 and De Groot, Obywatelstwo 2000, 7-36; De Groot, in: MüllerGraf 2002, 67-86.

38 De Groot, in: Müller-Graf 2002, 74-76; Juárez Peréz, 169, 170.

39 De Groot, in: Müller-Graf 2002, 73.

40 De Groot, Aruba 1993, 43-48; and De Groot, MR 2000, 51-52. Compare also: Burgers-Vos, 3-15 and Martha, 205-211.

41 See De Groot, in: Müller-Graf 2002, 74-76 with further references. For a different opinion: Hartley, 77-80; Mortelmans/Temmink, 51-91, in particular 63, 64.

42 Argentina, Bolivia, Chile, Costa Rica, Dominican Republic, Ecuador, Guatemala, Honduras, Columbia, Nicaragua, Paraguay and Peru; for further information see Aznar Sanchez, 1977 and more recently: Alvarez Rodriguez 2000 and Coppa 2002.

43 See Artt. 2 (1) and 6 (a) Directive 73/148 (establishment and services) and Artt. 3 (1) and 4 (3) (a) Directive 68/360 (workers).

44 De Groot, MJ 2002, 115-120. 
nationality 45 which was modelled on the Spanish-Argentinean treaty.

In addition to these borderline cases of European citizenship, it is worthwhile to study the rules in force in different Member States that allow descendants of former nationals living abroad to acquire the nationality of their ancestors. Considerable differences can be observed between these rules. Some Member States are very restrictive in respect of access to citizenship for descendants of former nationals residing abroad. Other States are extremely liberal. Since 9 January $2003^{46}$ Spain, for example, grants a right to opt for Spanish nationality to all children born of a parent, who originally possessed Spanish nationality and was born in Spain (Art. 20 (1) (b) Código civil). The declaration to opt for Spanish nationality can also be made outside Spain. The option right is not limited in respect of the age of the person involved. The grandchildren of persons who originally possessed Spanish nationality, will be able to acquire Spanish nationality by naturalisation after a residence period of one year (Art. 22 (2) (f) Código civil). Italy offers rather similar access to Italian nationality for the children and grandchildren of Italian emigrants. 47

As a result of the new Spanish option right for the children of former Spanish nationals born in Spain, Fidel Castro himself could immediately opt for European citizenship, while continuing to reside in Cuba. 48

45 Treaty of 29 October 1971; in Italy approved by Act of 18 May 1973, Nr. 282, Gazetta Ufficiale 1973, Nr, 152.

46 Act $36 / 2002$ of 9 October 2002, BOE 2002, 35638-35640. See on this new act: Alvarez Rodriguez 2002, 47-86.

47 See Artt. 4 and 9 Legge sulla cittadinanza italiana of 5 February 1992, Gazetta Ufficiale 15 February 1992, Nr. 38 and Art. 1 of the Act Nr. 379 of 14 December 2000, Gazetta Ufficiale Nr. 295 of 19 December 2000.

48 Fidel Castro's father, who was born in Galicia (Spain), went to Cuba at the end of the 19th century. See 'Noticias de Cuba', available on: http:/www.cubanet.org/CNews (last visited on 25 October 2003). According to Spanish estimations, some 80,000 persons residing in Cuba have this option. 


\section{Autonomy in Matters of Nationality}

The special "Declaration (no 2) on nationality of a Member State" quoted earlier, which was attached to the Maastricht Treaty, gives the impression that each Member State is fully autonomous in regulating nationality. The conclusion that Member States continue to have full autonomy, cannot be maintained, however, in all circumstances.

We may first of all observe that the relation between the first and second sentence of the (Maastricht) Declaration on nationality is not entirely clear. The first sentence grants the Member State in question a right to determine who is a national of that Member State. The nationality of a Member State is to be determined exclusively on the basis of the national law of that Member State and not by Community law. The second sentence, however, offers the Member States the possibility to issue an additional declaration 'for information' regarding the persons who possess the nationality of a Member State. Does this second sentence entail that the Member States can exclude some groups of their nationals from the rights under the EC Treaty? Can they grant these rights to groups of individuals, who do not possess the nationality of these Member States under their nationality law? Or are they only permitted to offer an authoritative explanation of their nationality laws as to who exactly is a national of the Member State involved in case of reasonable doubt? Obviously, the other Member States need to know whether they should also regard British Overseas Citizens to be British citizens for Community purposes. 49 Is it possible for the Netherlands, for example, to declare that all Netherlands citizens born outside the territory of the Kingdom of the Netherlands are not Netherlands citizens for Community purposes?

Upon consultation of the Netherlands law of citizenship there can be no reasonable doubt whether or not children of Netherlands citizens born abroad are Dutch. They acquire Netherlands citizenship at birth, jure sanguinis; a declaration to the contrary, therefore, addressed at the Presidency of the European Community, would be rather surprising. Would such a declaration perhaps violate the aim of Article 17 of the

49 Compare Jessurun d'Oliveira 1999, in: O'Keeffe/Twomey, 440 who stresses that the United kingdom and Germany had reasons for issuing a declaration, because they have non-standard nationality legislation. 
Treaty? The answer to this question depends, inter alia, on the interpretation of the second sentence of the additional declaration. Does it allow total freedom to make any conceivable declaration regarding the determination of the nationals of a Member State?

And what exactly is the purport of the words 'for information' and 'when necessary' in that second sentence?

However, I have already mentioned that two Member States, Germany and the United Kingdom, issued special declarations on the issue of who must be regarded as their nationals for Community purposes. Both Member States did not simply "explain" their nationality legislation, but created a special, functional nationality for Community purposes. This observation is of relevance to the interpretation of the words 'for information' in the declaration on nationality attached to the Maastricht Treaty. These words obviously do not exclude the possibility that determination of nationals for Community purposes deviates from the general definition of "nationals".50 From this perspective, it is likely that the Netherlands can exclude nationals born abroad from European citizenship without violating the Treaty.

Some doubt about full autonomy in matters of nationality also arises from reading the decision of the European Court of Justice of 1992, in Michelleti.51 The Court decided that Spain had to accept that Mario Vincente Micheletti, who had been born in Argentina as the son of an Italian father, an Argentinean national through naturalisation, was to be regarded an Italian for Community purposes, because of the Italian interpretation of the content of an Italian/Argentinean treaty on dual citizenship, which in fact was a copy of the Spanish/Argentinean treaty on dual citizenship. Under similar circumstances, based on its treaty with Argentina, Spain would have concluded that a child of an original-

50 See also Evans 1998, in: La Torre, 267-293 with reference to Case T 230/94 Frederick Farrugia v. EC Commission.

51 ECJ 7 July 1992, Case 369/90, ECR 1992 I-4258: Mario Vincente Micheletti and others/Delegación del Gobierno en Cantabria. See on this case: Borras Rodriguez, RJC 1993, 584-587; Carracosa, TINLP 1994, 7-12; Espinar Vicente, La Ley 1994, 1-5; De Groot, MR 1992, 105-110; Iglesias Buhigues, 953-967; Jessurun d'Oliveira, CMLR 1993, 627 ff.; Ruzié, 107-120; Sebastien, RDP 1993, 1263-1269. On the reaction of the Spanish courts: De Groot, MR 1998, 117, 118. 
ly Spanish parent, who had acquired Argentinean nationality through naturalisation, would not qualify as Spanish national for Community purposes. The European Court of Justice stressed respect for Community law when regulating and interpreting the nationality law of the State involved:

'The definition of the conditions of acquisition and loss of nationality is, in conformity with international law, within the competence of each Member State, which competence must be exercised with due regard to Community law.'52

An essential question is why the Court emphasised that this competence had to be exercised with due regard to Community law, although, thus far, the European Union has not adopted any Regulation or Directive on nationality law.53 In view of the declaration by the heads of government referred to earlier, attached to the Maastricht Treaty54, it is not very likely that such a Regulation or Directive will be prepared in the near future. 55

Nevertheless, it is my view that the nationality legislation of a Member state could conceivably violate general principles of Community law. ${ }^{6}$ This could be the case, when Member States regulate

52 See also ECJ 11 November 1999, Case 179/98. ECR I-7955, in re: Fatna Mesba, Nr. 29.

53 The only attempt to exert some influence on nationality matters was a resolution of the European Parliament of 18 September 1981, Official Journal 1981 C 260/100, where, on the occasion of a debate regarding the British Nationality Act 1981, it was concluded that a certain degree of harmonisation of nationality law should be promoted so as to avoid that persons were born stateless within the territory of the Community.

54 See also the Declaration of the European Council in December 1992, OJ 1992 C 348/1.

55 The autonomy of Member States in nationality matters was recently underlined in a written answer by Commissioner G. Verheugen to a written question posed by a Member of the European Parliament on the position of stateless persons in the candidate Member State Slovenia; E-1641/03.

56 See also Kotalakidis, 310: '... die Grenzen der Rechtmäßigkeit einer nationalen Staatsangehörigkeitsregelung, bzw. ihre Rechtswirkungen im Hinblick auf die Unionsbürgerschaft [können] anhand des Unionsrechts überprüft werden ....'. Compare also Kotalakidis, 316. 
the grounds for acquisition and loss of nationality:

a) violating the obligation of solidarity (Gemeinschaftstreue). A violation of this principle laid down in Article 10 EC could be observed, if a Member State were to grant its nationality to an important part of the population of a non-EU Member State, without prior consultation with Brussels. 57

The same holds true for the situation in which a Member State issues a declaration regarding the determination of nationals for Community purposes, with the inclusion of an important part of the population of a non-EU Member State, without previously consulting Brussels.

If, for instance, the Netherlands were to suddenly grant Netherlands nationality to the entire population of Surinam or an important part thereof, it could be argued that this would constitute a violation of the obligation of solidarity. $5^{8}$ Nevertheless, much depends, of course, on the reaction or non-reaction of the other Member States and the Commission.

The recent history of UK nationality law offers three examples of extending British citizenship (and therefore European citizenship) to (part of) the population of a non-European territory. During the Falklands war, an Act of Parliament59 was passed granting British nationality to all British Dependent Territories Citizens living on the Falkland Islands (who had not been European citizens, with the exception, perhaps, of those who were also Argentinean through Italian descent). Briefly before the transfer of the territory of Hong Kong to China, part of the population of Hong Kong was granted the right to opt

57 See Hall 1995, 64-73, who also pays attention to the procedures that need to be followed, if duties imposed by Article 10 have been violated.

58 This example has not been invented at my desk. Prime Minister Lubbers of the Netherlands made this suggestion as a 'political possibility' in a speech held in 1992. An advantage of such extension of Netherlands nationality would be that Netherlands nationals with ties with Surinam would perhaps take the decision to re-emigrate to Surinam more readily. See on this proposal also Kotolakidis, 299.

59 British Nationality (Falkland Islands) Act 1983.

60 British Nationality (Hong Kong) Act 1997. 
for British citizenship.60 More recently, on 21 May 2002, most British Overseas Territories Citizens became European citizens through their being granted British citizenship. ${ }^{61}$ In none of these instances did the European Commission or other Member States voice protest. Nor have the amendments of the treaties on dual nationality, concluded between Spain and Latin American countries, which entitled persons of dual Spanish-Latin American nationality to apply for a Spanish passport, led to protests.

Nevertheless, it cannot be precluded that in extreme circumstances a Member State will violate the obligation of solidarity by a surprising grant of their nationality. Kotalakidis 62 poses the question of what the reaction of the Commission and the other Member States would have been, had Cyprus not been accepted as a Member State and Greece -as a reaction to that- had granted Greek nationality - and therefore European citizenship - to all Cypriots of Greek ethnicity.

Jessurun d'Oliveira 63 has argued against the possibility that granting nationality without consulting the European Union may violate the obligation of solidarity between the Member States. He sees the reunification of the two German States after the fall of the Berlin wall and the increase in German nationals by approximately 18 million persons as illustration of a Member State's absolute autonomy in matters of nationality, in which the consent of the European Union is not required. I find this illustration far from convincing. Because of the earlier mentioned German declaration on nationality made in 1957, the entire population of the Democratic Republic of Germany already belonged to the group of persons that were German for Community purposes: the population of the Federal Republic of Germany.

An good example of the absolute autonomy of a Member State in nationality matters would have been the situation in which, conversely, the Federal Republic of Germany had deprived the population of the Democratic Republic of Germany of their German nationality without consulting the European Union. But that did not happen: Germany just main-

61 See above paragraph 3.

62 Kotalakidis, 299.

63 In: O'Keefe/Twomey, 402, 403. 
tained its old position, which it had expressed more than 30 years before. Jessurun d'Oliveira then continues 64 :

'Owing to the fact that neither Member States, not the Commission, nor the Council or any other Community institution have called since 1957 for any revision or implementation -no matter how spectacularof the nationality law of Member States, it appears that lack of solidarity with the Community in this area is not an issue.

Or, in other words, historically speaking nationality law is an absolutely irrelevant category in the framework of the new Article 10. Member States and Community institutions do not easily consider asking whether nationality laws of Member States are compatible with Community law. To date there has been no demand for information by the Member States from the Commission or Council, and there is no question of there being any co-operative, consultative or informative obligations in the absence of any sign of activity by the Community institutions.'

To my knowledge, it is true that the Commission or Council did not expressly request information of a Member State on nationality matters on the occasion of it amending nationality legislation. It seems to me, however, that in any case the Spanish treaties on dual nationality 65 and the British declaration on nationality after the 1981 review of British nationality law were discussed with the European authorities. Furthermore, in a Resolution on the occasion of the 1981 British declaration, the European Parliament stressed the desirability of some degree of harmonisation of nationality law. 66

b) A second limitation of Member State competence in nationality matters could be observed, if domestic rules on acquisition or loss of nationality violated public international law, especially fundamental rights guaranteed under international law. ${ }^{67}$

64 In: O'Keeffe/Twomey, 405; compare also pp. 409, 410.

65 Compare Perez Vera, RIE 1981, 685: '... es un aspecto del Derecho español de nacionalidad que parece despertar serias reservas en ciertos juristas communitarios que abogarian por su modificacion.'

66 Official Journal 1981, Nr. C 260/100.

67 Likewise Kotalakidis, 312, 313; differently Kovar/Simon, CDE 1994, 291. See also Hall, ELR 1996, 129-143. 
If a person has acquired the nationality of a Member State as a result of the application of a rule that violates international law, other Member States are entitled to treat that person as not possessing that nationality and, consequently, as a non-European citizen. This conclusion is in line with the general reaction to attribution of nationality in violation of international law. 68 More complex is the situation in which deprivation of nationality is in breach of rules of public international law. If a person has been deprived of the nationality of a State as a result of the application of a rule that violates international law, the generally accepted view is that other States should not regard such withdrawal of nationality as not having taken place. If they were to do that, they would not activate the international rules, or as the case may be, the national rules aiming to reduce cases of statelessness. 69 Within the framework of the European Union, a different, more effective approach is needed. If a person were to be deprived of the nationality of a Member State in violation of public international law, other Member States and the Union would be obliged to treat that person as continuing to possess European citizenship.70

c) The most important limitation of the autonomy of Member States in matters of nationality is without a doubt the guarantee of the right of free movement of persons within the European Union. ${ }^{11}$ The fundamental right of free movement within the European Union may, for instance, be violated, if a national of a Member State would lose his nationality -and therefore the status of citizen of the Unionif he lived abroad in another Member State during a certain period of time. The use of the right of free movement guaranteed by the EC Treaty in conjunction with such a regulation would cause loss of nationality and as a result -in some cases- loss of the status of European citizen. Such a national rule is incompatible with Community law.

68 See De Groot 1989, 17-23, with further references.

69 See De Groot 1989, 22.

70 Compare also O'Keeffe/Bavasso, in: La Torre, where they stress that, once an individual has obtained the status of European citizen, judicial control by the ECJ of cases of deprivation of Member State nationality is perfectly admissible in the light of the effects that this measure will produce on European citizenship rights. See also Hall 1995, 9,10,99 and Kotalakidis, 313.

71 Compare Greenwood, YEL 1987, $185 \mathrm{ff}$. 
Let us assume that the Netherlands was to amend the provision of Art. 15 (1) (c) Netherlands Nationality Act as follows72: 'Netherlands nationality shall be lost by any Netherlands national, who also possesses another nationality and, after having reached majority, has lived for an uninterrupted period of ten years outside the Netherlands, the Netherlands Antilles or Aruba, other than in the service of the Netherlands or the Netherlands Antilles or of an international organisation in which the Kingdom is represented, or as the spouse of a person in such service.' In some instances, application of this rule would constitute a violation of Community law. This would be the case, if a person possessed both Netherlands nationality and the nationality of a non-EU State. After having lived for a period of ten years in, for instance, Germany, he would lose his Netherlands nationality and consequently the status of European citizen. This result is especially unacceptable in cases where the citizen in question is not able to renounce his non-EU nationality, due to the domestic nationality rules of the non-EU State involved, Venezuela being a case in point. 73

It must be pointed out that I did not invent this possible amendment of Art. 15 (1) (c) Netherlands Nationality Act, but simply paraphrased an amendment proposed in a Bill74 presented to Parliament by the Netherlands government on 25 February 1993.75

However, on 16 September 1993, the government modified the proposed new article: Netherlands nationality shall not be lost, if the person involved is residing within the territory of the European Union76 and furthermore the loss can be prevented by possessing a Netherlands passport or a certificate of possession of Netherlands nationality.77 The

72 See also Kotalakidis, 314.

73 It must be borne in mind that a considerable number of persons possesses both Netherlands and Venezuelan nationality (the one jure sanguinis, the other jure soli), partly due to the fact that Venezuela is a neighbouring country of the Caribbean part of the Kingdom of the Netherlands and partly due to the activities of Shell Oil Company in Venezuela.

75 See page 26

76 see page 26

77 See page 26 
government defended this modification of the proposed amendment by arguing that the text originally proposed might have violated the right of free movement within the European Union. 78

Jessurun d'Oliveira79 does not agree with the conclusion that loss of nationality by reason of continuous residence abroad may violate the free movement rights under the EC Treaty. He argues as follows:

'It has been put forward80 that it would be incompatible with Community law if one Member State were to rule that a national residing in one of the other Member States and having no other nationality should lose his nationality, for example, after having lived there for more than ten years. The party concerned would indeed, the

75 Voorstel van Rijkswet tot wijziging van de Rijkswet op het Nederlanderschap, wetsontwerp 23029 (R 1461). The complete text of the proposed new Article 15 reads:

'1. Het Nederlanderschap gaat voor een meerderjarige verloren:

a) door het afleggen van een verklaring van afstand;

b) indien hij tevens een vreemde nationaliteit bezit en tijdens zijn meerderja righeid gedurende een ononderbroken periode van tien jaar in het bezit van beide nationaliteiten zijn hoofdverblijf heeft in het buitenland, anders dan in een dienstverband met Nederland, de Nederlandse Antillen of Aruba dan wel met een internationaal orgaan waarin het Koninkrijk is vertegenwoordigd, of als echtgenoot van een persoon in een zodanig dienstverband.

2. Het in het eerste lid, onder b, bepaalde is niet van toepassing op de Nederlander die tijdens zijn meerderjarigheid die vreemde nationaliteit verkrijgt.

3. De in het eerste lid, onder b, bedoelde periode van tien jaar wordt geacht niet te zijn onderbroken indien de betrokkene gedurende een periode korter dan één jaar zijn hoofdverblijf in Nederland, de Nederlandse Antillen of Aruba heeft.'

76 Literally, the relevant provision provides that nationality may be lost if the person in question is living outside the territories to which the Treaty on the European Union is applicable ('buiten de gebieden waarop het Verdrag betreffende de Europese Unie van toepassing is'). As a result, the loss may occur in the event of residence in an overseas territory of a Member State, such as the Faroe Islands, French Polynesia or Saint Helena.

77 The new rule came into force on 1 April 2003. See De Groot, Handboek 2003, 374-380 and Vrinds, StAZ 2004, 1-9.

78 Memorie van Antwoord, 8, 9. See for more details on this modification: Jessurun d'Oliveira, in: O'Keeffe/ Twomey, 408, 409.

79 In: O'Keeffe/Twomey, 406, 407.

80 He refers to my earlier publications on this issue. 
argument runs, lose the protection of the EC Treaty, namely entitlement to the freedom of movement. Worse still, if he lost his Member State nationality he would lose his Union citizenship as well.

There are two objections to this example. In the first place I submit that everything has been turned upside down. Whoever is a national of a Member State is a Union citizen, with all the rights and entitlements that result from that status.

Whoever is not (or not longer) a national of a Member State is not (no longer) eligible for Union citizenship. A Union citizen is not robbed of the rights he or she is entitled to under the Treaty, but the grounds for his or her Union citizenship and the resulting rights are cancelled as the premise for Union citizenship is no longer fulfilled.

Secondly, the position is rather timid. The implication of the standpoint that someone residing in a different Member State of the EC may not lose his or her nationality is that in the end all regulations concerning the loss of nationality are fundamentally forbidden under Community law, because they go hand in hand with the loss of Community rights. Should, for instance, Article 14 (2) of the Dutch Nationality Law then come to read: '[n]o loss of Dutch nationality in any case takes place whatsoever should someone become stateless or lose Union citizenship as a result'?'

I have to make clear first of all that Jessurun d'Oliveira has not summed up my arguments entirely correctly. After the words 'having no other nationality' the words 'of another Member State' must be added; this makes a vast difference.

Secondly, I disagree with his first argument. The nationality involved would be lost merely because of residence abroad, which is allowed and even guaranteed under the EC Treaty. It is therefore the exercise of rights granted by Community law that leads to the loss of European citizenship. That, in my opinion, is not acceptable.

His second argument is not at all convincing. I never wrote that a national of a Member State residing in another Member State may not lose his or her nationality. My argument was basically that residence abroad in another Member State, as the only ground for loss, is extremely problematic in view of Community law.

Jessurun d'Oliveira81 also calls attention to the fact that not all

81 In: O'Keeffe/ Twomey, 407. 
nationals of a Member State residing in another Member State remain there as a result of residence permits granted under EC law. That is correct and my reason for always emphasising that loss of nationality on the ground of residence abroad may violate Community law. I am perfectly aware that this is exclusively the case, in principle, if residence abroad was guaranteed by EC law. However, it should also be borne in mind that, more and more frequently, the European Court of Justice underscores the importance of European citizenship itself as a fundamental status.

This could have future consequences in that the possession of European citizenship is always protected in case of residence within the territory of the Union. 82

Loss of nationality on the ground of uninterrupted residence abroad is not only provided for in Dutch nationality legislation, but also in the legislation of some other Member States. Belgium so provides since $1985^{83.84}$

82 Doubts about compatibility with European law may arise in following case: a Belgian national acquires Netherlands nationality by naturalisation. As a result, he loses Belgian nationality. Later on it is discovered that he failed to inform the competent authorities of the Netherlands that at the time of the application for naturalisation criminal investigations had been instituted against him in Belgium. Because of this fraudulent concealment of facts relevant to the naturalisation, he is deprived of his Netherlands nationality. As a consequence, he becomes stateless (based on Art. 14 (1) Netherlands Nationality Act as amended, since 1 April 2003). It is - to put it mildly - remarkable that a European citizen loses this status as a consequence of criminal behaviour, in spite of the fact that he continues to reside within the territory of the Union. Again, the example has not been invented, but was taken from the official governmental instruction for the application of the revised Netherlands Nationality Act (Handleiding voor de toepassing van de Rijkswet op het Nederlanderschap 2003, 's Gravenhage: SDU (loose-leaf edition), commentary on Art. 14).

83 Carlier/Goflin, in: Nascimbene (ed.), 146, stating that the provision, inspired by Denmark and the Netherlands, was incorporated into Belgian law in 1985 . They refer to Doc. Parl. Chambre, sess. ord. 1983/84, 21, p. 122.

84 See also Art. 8 (1) Danish Nationality Act, Art. 34 Finish Nationality Act, Art. 8 Icelandic Nationality Act, Art. 25 (8) Luxembourg Nationality Act, Art. 14 Swedish Nationality Act. Compare also Artt. 23-6 French Civil Code, Section 19 (1) (c) Irish Nationality and Citizenship Act and Art. 24 Spanish Civil Code. See for a comparison of these provisions: De Groot, Loss 2003, in: Martin/ Hailbronner, 241-246. 
However, in my opinion, a technical detail of the corresponding Belgian provision ensures that the Belgian legislation does not violate Community law. The relevant part of Article 22 Belgian Nationality Act reads:

'§ 1 er. Perdent la qualité de Belge: ....

$5^{\circ}$ le Belge né à l'étranger à l'exception des anciennes colonies belges lorsque:

a) il a eu sa résidence principale et continue à l'étranger de dix-huit à vingt-huit ans;

b) il n'exerce à l'étranger aucune fonction conférée par le Gouvernement Belge ou à l'intervention de celui-ci, ou n'y est pas occupé par une société ou une association de droit belge au personnel de laquelle il appartient;

c) il n'a pas déclaré, avant d'atteindre l'âge de vingt-huit ans, vouloir conserver sa nationalité belge; du jour de cette déclaration, un nouveau délai de dix ans prend cours.

§3. Le $\$ 1 e r, 50$ et 60, ne s'applique pas au Belge qui, par l'effet d'une de ces dispositions, deviendrait apatride.'

As with the Netherlands, it is possible, therefore, that a Belgian national loses Belgian nationality and, as a result, European citizenship, while exercising the right of free movement of persons in another Member State of the European Union after a residence of ten years abroad. However, by submitting a declaration of extension of nationality to the Belgian authorities in due time, loss of Belgian nationality can be avoided. Clearly, there may be cases, in which the person in question simply forgets to submit such a declaration. Nevertheless, in no such case would I conclude that Community law has been violated. It is not unacceptable that a citizen must submit such a declaration. In its decision in Factortame, the European Court of Justice 85 emphasised within the context of the obligation to pay compensation for damages as a result of a violation of Community law, that the injured party must demonstrate reasonable diligence in avoiding loss or damage, or in limiting its extent, and must make use of all legal remedies available (par.

85 EJC 5 March 1996, Case 46/93 and Case 48/93, ECR I-1029. 
84 of the Judgment). Bearing this principle in mind, one could argue in respect of nationality law that the persons in question cannot complain that Community law has been violated, where they could have avoided damage had they submitted a simple declaration.

Another violation of the free movement rights guaranteed under the EC Treaty would result from the situation, in which children of nationals of a EU Member State, because they were born in another Member State, do not acquire the nationality of the state of origin of their parents pursuant to domestic nationality rules. 86

According to Article 8 of the Belgian Nationality Act, nationality may be acquired by 1) any child of a Belgian parent born in Belgium or 2) any child of a Belgian parent born abroad, if one of three conditions is fulfilled: a) the parent was born in Belgium or in territories under Belgian administration; b) the Belgian parent registers the child as a Belgian national within five years of its birth; c) the child is otherwise born stateless or loses his (other) nationality before his eighteenth birthday. ${ }^{87}$ When reading these conditions, one can conceive of cases, in which a child of Belgian parents does not acquire Belgian nationality (and therefore European citizenship), while the parents exercise their European citizenship right in another EU Member State. However, the parents can always register their children as Belgian citizens. ${ }^{88}$ Although this, per-

86 Apart from the Belgian and German provisions described here, comparable regulations exist in the United Kingdom (SS. 2 and 3 BNA), Ireland (Sect. 7 (3)) and Portugal (Art. 1 (1) (b) Nationality Act). See for details of these provisions De Groot, Acquisition 2002, 125-129.

87 Art. 8 (1) reads: § 1er. Sont Belges:

$1^{\circ}$ L'enfant né en Belgique d'un auteur belge, $2^{\circ}$ L'enfant né à l'étranger:

a) d'un auteur belge né en Belgique ou dans des territoires soumis à la souveraineté belge ou confiés à l'administration de la Belgique;

b) d'un auteur belge ayant fait dans un délai de cinq ans à dater de la naissance une déclaration réclamant, pour son enfant, l'attribution de la nationalité belge;

c) d'un auteur belge, à condition que l'enfant ne possède pas, ou ne conserve pas jusqu'à l'age de dix-huit ans ou son émancipation avant cet âge, une autre nationalité. 88The possibility of registration is an important difference compared to the British provisions.

88 The possibility of registration is an important difference compared to the British provisions. 
haps, involves some nuisance to the parents, they are able to avoid all nationality disadvantages to their children by opting for Belgian citizenship for their child in due time (within five years of the birth of the child). Basing myself on the ruling by the European Court of Justice in Factortame, in which the Court stressed that there is an obligation to avoid damage, where possible, I have reached the conclusion that Belgian parents cannot complain about Belgian legislation on the acquisition of nationality at birth breaching Community law, if they themselves "forget" to submit a declaration to the Belgian authorities. Within this context, it is important that the time limit within which the child is to be registered is reasonable one. The parent's Belgian passport is normally valid for a period of five years. The Belgian parent will therefore have to contact a Belgian consulate at least every five years to obtain a new passport. On that occasion, he or she can register the child as a Belgian national. If the parent fails to do so, it may be assumed that non-registration is a conscious decision.

If registration of a child has to take place within a shorter period after birth, there may be some reservations as to the acceptability of the rule. Since 1 January 2000, the German Nationality Act provides in Article 4 (4) that German nationality will no longer be acquired by descent, if a child of German parent(s) is born abroad after 31 December 1999 and has his habitual residence outside of Germany ('wenn der deutsche Elternteil nach dem 37. Dezember $1999 \mathrm{im}$ Ausland geboren wurde und dort seinen gewöhnlichen Aufenthalt hat'). German nationality is nevertheless acquired, in the event that otherwise the child would be stateless. If the child does not acquire the German nationality of the parent(s) ex lege, because both parent and child were born abroad, a parent may register the child as a German national within one year of its birth. 89

89 This limitation of the transfer of German nationality is completely new in German nationality law, but it will take some time before this modification will have results in practice. The first children who will not acquire German nationality because of this limitation are the children of the German children born outside Germany in the year 2000. 
In my judgment, this time limit of one year is too short.90 It is not difficult to conceive of cases, in which parents are not aware that their child needs to be registered for it to acquire German nationality, since German law did not require registration before the year 2000. Such cases could prove problematic from a Community law perspective.

Another example of nationality provisions which may conflict with Community law is found in Article 23-8 of the French Civil Code:

'Art. 23-8. Perd la nationalité française le Français qui, occupant un emploi dans une armée ou un service public étranger ou dans une organisation internationale dont la France ne fait pas partie ou plus généralement leur apportant son concours, n'a pas résigné son emploi ou cessé son concours nonobstant l'injonction qui lui en aura été faite par le Gouvernement.

L'intéressé sera, par décret en Conseil d'État, déclaré avoir perdu la nationalité française si, dans le délai fixé par l'injonction, délai qui ne peut être inférieur à quinze jours et supérieur à deux mois, il n'a pas mis fin à son activité.

Lorsque l'avis du Conseil d'État est défavorable, la mesure prévue à l'al inéa précédent ne peut être prise que par décret en conseil des ministres.' 91

If the French authorities were to apply this provision to a national who is employed in the service of another EU Member State, this would constitute an obvious violation of Community law. Application of such a provision is incompatible with the objectives of the EC Treaty. .92

90 The same applies to the British requirement of registration within twelve months (S. 3 BNA). However, S. 3 (4) opens the possibility for the Secretary of State to allow registration after twelve months of the birth of the child, by providing that 'if in the special circumstances of any particular case the Secretary of State thinks fit, he may treat subsection (2) as if the reference to twelve months were a reference to six years.'

91 This provision corresponds with Article 96 of the preceding Code de la nationalité française.

92 Similar difficulties may arise in respect of Art. 20 (1) (b) Greek Nationality Act, Art. 12 (1) (1) Italian Nationality Act and Art. 25 (1) Spanish Civil Code. See for a comparison of those provisions: De Groot, Loss 2003, in: David/Hailbronner, 229-232. 


\section{Developments in the Near Future}

It may be observed that EU law has already had some impact on the nationality law of the Member States.93 For several reasons, it can be expected that in the near future the European Union will increasingly try to influence the grounds for acquisition and loss of nationality in the Member States.

First of all, the European Union's influence on matters of immigration law is growing. Because of the very close relationship between immigration regulations and nationality law, in particular the rules on naturalisation, it is quite likely that the Union will be tempted to influence naturalisation policies as well. 94

Secondly, it is striking how many differences exist for descendants of persons originating from the territory of a Member State in respect of access to European citizenship through acquisition of their ancestors' nationality. With regard to some nationalities, such acquisition is very easy95; in some other Member States the possibility does not exist. It will be difficult to continue to accept such unequal treatment of descendants of persons originating from the different Member States.

In the third place, at least two provisions in the Draft European Constitution give rise to questions with regard to issues of nationality. Article 24 of the Draft Constitution provides that where the European Council or the Council of Ministers must take decisions by qualified majority, 'such a majority shall consist of the majority of Member States, representing at least three fifths of the population of the Union.' Such

93 In a similar vein, Kotalakidis, 316.

94 Compare the situation in the United States where as early as 1789 in Art. I, sec. 8, clause 4 of the Constitution of the United States it was provided: 'The Congress shall have Power ... to establish an uniform Rule of Naturalization.' The right to enact rules dealing with naturalisation was granted to the Union, because otherwise the States of the Union might have developed different policies on naturalisation and immigration. In the early existence of the United States, other rules of nationality law, especially rules regarding acquisition by birth and loss of nationality were regulated by the different States, not by the Union. Only after the 14th Amendment (Section 1) came into force (in 1868) did the subject of nationality become governed by federal legislation.

95 See on these facilities De Groot, Acquisition 2002, 149, 150, 153. 
qualified majority is to take effect on 1 November 2009, after the elections for the European Parliament.

The crucial term "population" lacks definition, however. The following interpretations are therefore possible:

a) all persons residing in a Member State. However, this would imply aliens as well;

b) residents of a Member State who possess the nationality of that Member State;

c) residents of a Member State, who are European citizens;

d) all persons possessing the nationality of a Member State (including expatriates).

It is obvious that the choice for one of these options will considerably influence the size of the "population" of some Member States. In several (future) Member States, a high percentage of aliens reside (Germany, Baltic countries). Some other (future) Member States have very high numbers of expatriates (Baltic countries, Greece, Hungary, Ireland, Italy Poland and Spain). If the Intergovernmental Conference wishes to hold on to the solution proposed in the Draft Constitution, it is imperative that the term "population" be defined. 96

Another nationality-related issue in the Draft Constitution concerns the rotation system for Commissioners proposed by Article 25 (3), which provides:

'The Commission shall consist of a College comprising its President, the Union Minister of Foreign Affairs/Vice-President, and thirteen European Commissioners selected on the basis of a system of equal rotation between the Member States. This system shall be established by a European decision adopted by the European Council on the basis of the following principles:

96 Otherwise it is to be preferred to preserve the compromise of Art. 3 (2) Protocol Nice Treaty, OJ C 80 of 10 March 2001. The Nice Treaty came in force on 1 February 2003. 
(a) Member States shall be treated on a strictly equal footing as regards determination of the sequence of, and the time spent by their nationals as Members of the College; consequently, the difference between the total number of terms of office held by nationals of any given pair of Member States may never be more than one;

(b) subject to point (a), each successive College shall be composed as to reflect satisfactorily the demographic and geographical range of all Member States of the Union.'

The new composition of the Commission is intended to be operative as of 1 November 2009 as well. A nationality-related problem is caused by the use in Article 25 (3) (a) of the word "nationals". Obviously, the framers of the Constitution were not aware that an increasing number of European citizens have dual or multiple nationality.

Many possess the nationality of more than one Member State. What if a Belgian Commissioner is appointed, who also happens to possess Italian nationality? Would that entail that no other Italian national can serve as Commissioner at the same time? I submit that a different formulation is needed.

The formulation of Article 25 (3) is obviously inspired by the formulation of Article 213 (1), last sentence, EC Treaty (ex Art. 157 (1) EC): 'The Commission must include at least one national of each of the Member States, but may not include more than two Members having the nationality of the same State.' However, the formulation of the proposed Article 25 (3) is slightly stricter than that of Article 213 (1) EC. Moreover, times have really changed. Forty, fifty years ago dual or multiple nationality was a rather rare phenomenon. Nowadays, at the beginning of the twenty-first century, the number of cases of dual and multiple nationality is growing rapidly and such cases are becoming more and more normal.97The above formulations need clarification or should be rephrased. Whatever the result of this exercise, it is clear that the debate on these issues has opened our eyes to the remarkable differences in the

97 This applies in particular to those specialised in European law. I know of several professors of European law who possess the nationality of more than one Member State of the Union. 
Member States in the area of nationality.

The impetus for reflecting on Community influence on the nationality laws of the Member States has without a doubt been given by the debate on the position of third-country nationals permanently residing within the territory of the Member States. The leaders of the European Union (EU) already declared on the occasion of the European Council in Tampere (Finland), held on 15 and 16 October 1999, that third-country nationals who had been legal residents of a EU Member State for some time, should be granted a right of free movement within the European Union. In March 2001, the European Commission presented a proposal for a EU council directive on granting special status to third-country nationals who had been long-term residents in the European Union. Recently, on 5 June 2003, the ministers of justice and home affairs of the EU Member States agreed on this directive. 98

The requirements which must be met in order to acquire the status of long-term resident are laid down in Articles 4-7 of the Directive. Member States will grant long-term resident status to third-country nationals who have been legally residing in that Member State for an uninterrupted period of five years (Art. 4 (1), providing they possess a minimum level of resources (Art. 5 (1)) 99 and do not constitute a threat to public order or public security (Art. 6). Periods of absence of less than six consecutive months will not interrupt the period of legal and continuous residence and will be included for the purposes of calculating the required residence period, on the condition that the periods of absence do not exceed a total of ten months(Art. 4 (3)). ${ }^{100}$ Persons being granted long-term residence status are issued with a residence permit

98 Council Directive 2003/109/EC van 25 Nov. 2003, OJ 2004 L 16/44. The directive is not binding on Denmark, Ireland and the United Kingdom. Another directive is being drafted by the European Commission on the extension of long-term resident status to refugees and persons enjoying subsidiary protection.

99 In the 2001 draft directive, this condition did not apply to refugees and thirdcountry nationals born within the territory of a Member State.

100 In addition, the 2001 Draft Directive provided that the same would apply to periods of absence related to the discharge of military obligations, detachment for employment purposes, studies, research, serious illness, pregnancy, maternity and -last but certainly not least - residence in another Member State as a family member of a citizen of the Union (or a long-term resident), exercising the right to free movement of persons. 
valid for at least five years, automatically renewable on expiry (Art. 8). Long-term residents have the right to reside in other Member States under the conditions given in Article $14 \mathrm{ff}$.

The conditions under which long-term resident status may be lost again are laid down in Article 9. Member States will withdraw long-term resident status, if it comes to light that the status was acquired by means of fraud (Art. 9 (1) (a)). Furthermore, it will also be withdrawn in the event of an expulsion measure in respect of the person in question (Art. 9 (1) (b) in conjunction with Art. 12). Article 9 (3) allows that Member States provide that long-term residence status will be lost in cases in which the person in question constitutes a threat to public policy, because of the seriousness of an offence committed, even if the offence does not constitute a ground for expulsion. ${ }^{101}$ The status is also lost as a result of acquisition of a similar status in another Member State (Art. 9 (4) (1)).

However, the most remarkable ground for losing long-term resident status is absence from the territory of the Community'102 for a period of twelve consecutive months. However, Article 9 (2) provides the following: 'By way of derogation from paragraph 1 (c), Member States may provide that absences exceeding twelve consecutive months or for specific or exceptional reasons shall not entail withdrawal or loss of status.'103

A rather weak point in the Directive is the provision that Member States may have different rules on loss of long-term resident status on the grounds of residence outside the territory of the European Union. ${ }^{104}$ It implies unequal treatment of groups of third-country nationals, which in the long run cannot readily be accepted. It is therefore desir-

101 This possibility was not provided for in the 2001 Draft Directive.

102 Consequently, long-term residence status may be lost in case of residence within an overseas territory of a Member State (such as Aruba).

103 In the 2001 Draft Directive, Article 10 (1) (a) provided: 'Member States may provide for derogations in the event of absence related to the discharge of military obligations, detachment for employment purposes, studies or research, serious illness, pregnancy or maternity.' And Article 10 (3) continued: 'Member States may provide that prolonged absences exceeding two years or related to reasons not referred to in paragraph 1 shall not entail withdrawal of long-term resident status.'

104 see page 38 
able to examine precisely how the different Member States will implement the directive with regard to loss of long-term residence status. It is also desirable to compare these loss provisions with the grounds for loss of the nationality of the different Member States. In this context, the question must be raised whether a period of residence abroad must be accepted as an exclusive ground for loss of long-term resident status or whether acts during a shorter residence abroad, which according to the nationality law of some Member States would cause the loss of the nationality, irrespective of the length of the residence period abroad (e.g. voluntary acquisition of a foreign nationality or voluntary military service), must be accepted as a ground as well.

These issues demonstrate that the introduction of long-term resident status will stimulate the debate on the differences in the Member States with regard to the grounds for loss of nationality.The creation of long-term residence status linked with free-movement rights will have yet another - even more important - consequence for the debate on the nationality laws of the Member States. Long-term residents will be granted a set of uniform rights affording them a legal status that approximates that of European citizens. They do not possess, however, European citizenship. How then will they be able to acquire European citizenship?

It is conceivable, in theory, that the European Union grants European citizenship ex lege to long-term residents, after they have enjoyed resident status for a certain period (e.g. five or ten years). ${ }^{105}$ However, it is unlikely that such a step will be taken soon. ${ }^{106}$ Such a regulation would imply the creation of a quasi-nationality entitling to European citizenship, as in the case of the nationalities of the Member States. It would make it necessary to regulate in detail by Community law the grounds for loss of such a quasi-nationality and the way in which such quasi-

104 Similar critical remarks are justified in respect of Article 3 (3) (2) and (4) and Article 5 (2), which allow Member States to introduce into national legislation additional requirements for third-country national to obtain long-term residence status. These possibilities did not exist in the $2001 \mathrm{draft}$ directive.

105 Compare the view by the European Parliament that it is desirable to create an autonomous notion of 'European citizenship', irrespective of the nationality of the Member States. See Castro Oliveira 1997, 207-223; Kotalakidis, 303. 106 See page 39 
nationality is transferred to descendants, in particular those born outside the territory of the European Union.

At the moment, the only realistic possibility of access to European citizenship is through acquisition of the nationality of a Member State by naturalisation or the exercise of an option right. The first problem to be encountered is an obvious one: the rules governing naturalisation differ considerably from Member State to Member State. ${ }^{107}$

Even greater variation can be observed between the rules of the different Member States governing the right to opt for nationality. ${ }^{108}$ From this perspective, harmonisation of the requirements for naturalisation would be desirable in any case. Harmonisation, or perhaps even unification, will prove necessary in respect of at least one of the requirements.

If a long-term resident intensively and frequently exercises the right of free movement within the territory of the European Union, by moving from one Member State to another, it could happen that he will not meet all requirements set by a Member State to qualify for naturalisation. He may have particular difficulties with the residence requirement: in many States five years or more must have lapsed109 before a person can apply for naturalisation. In other words, precisely the exercise of the freshly granted right of free movement may constitute an impediment to obtaining the ultimate status of European citizen. It seems obvious that the European Union must take action so as to avoid problems in this respect. It will be necessary to regulate that periods of residence in another Member State need to be (in any case partly) taken into account in calculating the required residence period for naturalisation. There are two options, which may be combined. On the one hand, it is desirable that the period of residence in another Member State is of relevance, if

106 However, the European Economic and Social Committee called for such a step in a self-initiated opinion on access to European Union citizenship of 14 May 2003: 'The EESC therefore proposes to the Convention that Article 7 (Citizenship of the Union) be granted not only to nationals of the Member States but to all persons who reside on a stable or long-term basis in the Union.' (see 6. Conclusions, Nr. 5, first sentence).

107 Walmsley, 95-107.

108 De Groot, Acquisition 2002, 144-154.

109 Walmsley, 99-101. 
a long term-resident wishes to apply for naturalisation in the new Member State to which he moved, after having received long-term residence status in the first Member State. It is also desirable, however, that long-term residents who recently moved from one Member State to another, retain their entitlement to naturalisation in the first Member State, while the residence period in the new Member State is considered to have at least some degree of relevance for the fulfilment of the naturalisation requirements in the first Member State.

An even more difficult issue are the language requirements set as a condition for naturalisation. An increasing number of Member States requires a reasonable command of (one of the) national language(s). ${ }^{110}$ It is arguable whether the condition is always reasonable with regard to third-country nationals with long-term residence status.

The question must unavoidably be raised as to whether it should be possible in certain circumstances to substitute deficient knowledge of the language of the country of residence by knowledge of the language of another Member State. This is a very sensitive issue in some countries, because command of one of the national languages is seen as an indication of a willingness to integrate into the country in question. Nevertheless, at present a third-country national who acquires the nationality of a Member State is entitled immediately upon naturalisation to settle in another Member State of the Union, although he does not speak a single word of the official language of that Member State. When the long-term residence directive comes into effect, this right will exist upon acquiring the newly created status. Should lack of language knowledge then block access to European citizenship in the country of residence? Similar observations can be made in respect of the requirement that a person applying for naturalisation has a reasonable knowledge of the society of the State, whose nationality he wishes to acquire. ${ }^{111}$

The problems relating to access to European citizenship experienced by third-country nationals who enjoy the right of free movement within the territory of the Union are not completely new. They have already

110 De Groot 1989, 254-256; Walmsley, 104, 105.

111 De Groot 1989, 250-254; Walmsley, 104. 
been faced by third-country nationals married to European citizens. The non-EU spouse of a European citizen suffers disadvantage in respect of fulfilling the residence requirement for naturalisation in a Member State, if the EU spouse decides to exercise his right of free movement in another Member State and expects the non-EU spouse to move with him (as is permitted under EU law). This problem is exacerbated if the EU spouse accepts work in yet another Member State every four or five years, which is not uncommon for workers in the service of certain multinationals. In spite of having lived for many years (even decades) within the European Union, the spouses of some EU nationals may have difficulties in acquiring European citizenship through the nationality of the Member State of residence. They have not yet lived there for the required period of time, nor have they fulfilled the conditions for the nationality of the country of origin of the EU-spouse, if in that country the residence requirement also applies to the national's spouse who wishes to become a naturalised national.

In some Member States, residence is not a requirement for the spouse of a national, but sometimes more hidden difficulties may exist, as in the case of the Netherlands. Article 8 (2) Netherlands Nationality Act provides that, in order to be eligible for Netherlands nationality by naturalisation, the residence requirement does not apply to applicants who have been married to Netherlands nationals for at least three years. Nevertheless, these applicants have to fulfil the condition of Article 8 (1) (d). They must be integrated ('ingeburgerd') into Dutch society, evidenced by a reasonable command of the Dutch language and a basic knowledge of the Dutch society ('maatschappij') and its constitution ('staatsinrichting'). It will be very difficult for the foreign spouses in question to satisfy these requirements, while living abroad in other Member States of the European Union. My conclusion is that this is also presents many problems in the light of free movement within the European Union.

Belgian nationality legislation also causes problems for alien spouses. Article 16 (2) Belgian Nationality Act contains rules on the acquisition of Belgian nationality by the alien spouse of a Belgian national: the alien in question may declare to opt for Belgian nationality, if the couple has been living together in Belgium for at least three years. The period of residence required is reduced to six months, if the alien spouse has been entitled to remain in Belgium longer than three months, for more than 
three years. ${ }^{112}$ The option declaration may be refused by the public prosecutor (procureur du Roi), 'lorsqu'il existe un empêchement résultante de faits personnelles graves qu'il doit préciser dans les motifs de son avis. '"13

Pursuant to the last sentence of Article 16 (2), the alien spouse living together with a Belgian national abroad, can be deemed to have satisfied the residence requirement, if genuine ties with Belgium have developed. This part of the provision reads as follows:

'Peut être assimilée à la vie commune en Belgique, la vie commune en pays étranger lorsque le déclarant prouve qu'il a acquis des attaches véritables avec la Belgique.'

With regard to this provision it must also be concluded that the fact that the couple is living abroad within the European Union, in the exercise of their right of freedom of movement, is not entirely taken into account. Compared to the position of a spouse of a national of the Netherlands, the situation does constitute an improvement, but all depends on the interpretation of 'attaches véritables avec la Belgique': do the ties established with another Member State of the European Union suffice to conclude that there are genuine ties with Belgium? Or are other, closer, ties required?

Action is needed to improve access to European citizenship by third-

112 Article. 16 (2) reads as follows:

'7.L'étranger qui contracte mariage avec un conjoint de nationalité belge ou dont le conjoint acquiert la nationalité belge au cours du mariage, peut, si les époux ont résidé ensemble en Belgique pendant au moins trois ans et tant que dure la vie commune en Belgique, acquérir la nationalité belge par déclaration faite [et agréée] conformément à l'article 15.

2. L'étranger qui contracte mariage avec un conjoint de nationalité belge ou dont le conjoint acquiert la nationalité belge au cours du mariage, peut, si les époux ont résidé ensemble en Belgique pendant au moins six mois et tant que dure la vie commune en Belgique, acquérir la nationalité belge par déclaration faite [et agréée] conformément à l'article 15, à la condition qu'au moment de la déclaration, il ait été autorisé ou admis, [au] moins trois ans, à séjourner plus de trois mois ou à s'établir dans le Royaume.'

113 Until 1 May 2000, the option declaration could also be refused if the willingness to integrate proved to be insufficient: 's'il y a des raisons, qu'il doit également préciser, d'estimer que la volonté d'intégration du déclarant est insuffisante.' 
country nationals married to European citizens. In the very near future, similar action will be necessary in favour of all third-country nationals, in particular third-country long-term residents, who exercise their right of free movement within the European Union.

\section{Conclusion}

The question must be posed as to how the European Union may exert influence on the nationality laws of the Member States, in particular the requirements for naturalisation. In this context, the activities of the Council of Europe in the area of nationality law must be pointed out. At its inception in the late forties of the last century, the Council of Europe was already active in the area of nationality law. Its most important achievement in this respect is the European Convention on Nationality (hereinafter abbreviated as: ECN) ${ }^{114}$, which was concluded in Strasbourg on 6 November 1997.115

The main importance of the ECN is that obligations and ideas that have emerged as a result of developments in both international and domestic law have gradually been consolidated into a single text. Most provisions of the Convention were inspired by provisions of a considerable number of other international instruments. ${ }^{116}$ The nationality provisions of these instruments have been adopted in the ECN, in some instances in a slightly elaborated form. Moreover, a number of provisions included in the Convention aims to contribute to the progressive development of an international law on nationality. This applies in particular to the provisions in Chapter VI on State succession and nationality.

The core articles of the ECN are Articles 6-9, in which rules on acquisition and loss of nationality are formulated. It is for the first time that an international treaty attempts to indicate which grounds for acquisition and loss of nationality are acceptable. Of particular importance are

114 See on the Convention: Autem, 19-34; De Groot, FJR 1998, 234-241; De Groot, AJ 1998, 28-49, De Groot, MJ 2000, 117-157; De Groot, MR 2002, 4-12; Jessurun d'Oliveira, Trends 7-47; Kreuzer, StAZ 1997, 125-132; Sabourin, 113-123; Saura Estapà 1998; Schade, AJPIL 1995, 99-103; Zilverentant, 49-52.

115 ETS 166; Trb. 1998, 10 and 149.

116 see page 44. 
Articles 7 and 8, which provide an exhaustive list of permitted grounds for loss of nationality. They are an important step towards harmonisation of the grounds for loss of nationality. Whereas the grounds for acquisition of nationality vary considerably from country to country, there is until now even greater divergence in the grounds for loss.

Articles 10-13 establish a number of rules on procedure. The ECN devotes four articles (Artt. 14-17) to cases of multiple nationality. These articles reflect an attitude of uncertainty: States may avoid cases of multiple nationality, but not under all circumstances. It is evidently intended that these provisions on multiple nationality must not form an obstacle to any State ratifying the Convention. As previously discussed, the Convention includes a number of articles (Artt. 18-20) on the principles that must be observed in case of State succession. The ECN also contains two articles (Artt. 21 and 22) on military obligations in cases of multiple nationality. These rules have been taken, without any substantive changes, from Chapter II of the 1963 Convention in conjunction with the provisions of the 1977 Protocol amending the 1963 Convention relating to alternative civil service and exemption from military obligations. Of great practical importance is that the Convention provides for cooperation between the States Parties in matters of nationality. Each State must provide the Secretary General of the Council of Europe with information on their internal law relating to nationality and on developments concerning the application of the Convention. Upon request, that

116 The 1930 Hague Convention on certain questions relating to the conflict of nationality laws, the 1948 Universal Declaration of Human Rights, the 1951 Convention on the States of Refugees, the 1954 Convention on the Status of Stateless Persons, the 1957 Convention on the Nationality of Married Women, the 1961 Convention on the reduction of statelessness, the Optional Protocols concerning Acquisition of Nationality to the 1961 Vienna Convention on Diplomatic Relations and the 1963 Vienna Convention on Consular Relations, the 1964 Convention of the International Commission on Civil Status on the exchange of information concerning acquisition of nationality, the 1966 International Convention on the Elimination of Racial Discrimination, the 1966 International Covenant on Civil and Political Rights, the 1967 European Convention on the Adoption of Children, the 1969 American Convention on Human Rights, the 1973 Convention of the International Commission of Civil Status to reduce the number of cases of statelessness, the 1979 Convention on the Elimination of All Forms of Discrimination against Women and the 1989 Convention on the rights of the child. 
same information has to be provided to other States Parties. The aim of the cooperation is to deal with all relevant problems, and promote good practice and the progressive development of legal principles concerning nationality and related matters (Art. 23 (2)).

To stimulate ratification, Article 29 is quite generous with regard to reservations. No reservations can be made in respect of the provisions contained in Chapters I, II and VI (i.e. Articles 1-5 (definitions and general principles) and Articles 18-20 (state succession)).

All other reservations are allowed, so long as they are compatible with the object and purpose of the Convention. Jessurun d'Oliveira'17 compares the Convention therefore to a super market where self-service is encouraged.

However, if a State makes a reservation, it has to apprise the Secretary General of the Council of Europe of the relevant content of its internal law or of any other pertinent information. The State in question is obliged to consider withdrawing the reservation as soon as circumstances permit.

If the European Union wishes to increase its influence on the Member States in matters of nationality, it should cooperate with the Council of Europe and not start all over again, developing its own rules on acceptable grounds for acquisition and loss of nationality. The European Union should take advantage of the experience and achievements of the Council of Europe. This is important in particular, because several Member States are signatories to the ECN or have already ratified the Convention. Until now, the ECN has been ratified by ten States and signed by another fifteen. Five Member States of the European Union have already ratified the ECN (Austria, Denmark, the Netherlands, Portugal and Sweden); of the States that will accede to the Union, Hungary and Slovakia are parties to the Treaty. Five other Member States (Finland, France, Germany, Greece and Italy) signed the Convention; of the future new Member States four have already signed (the Czech Republic, Latvia, Malta and Poland). One third of the Member States is therefore a party to the Convention; one third has signed it; and another one third has not, as yet, undertaken any action (Belgium, Ireland, Luxembourg, Spain and the United Kingdom). After 1 May 2004, the situation will be as follows: 7 Member States will have ratified the

117 Jessurun d'Oliveira, Trends, 46. 
Convention, 9 will have signed it and 9 will have undertaken no action. It would be a good and elegant first step towards some degree of harmonisation of the rules on acquisition and loss of nationality, if the European Union were to encourage that the Member States sign and ratify the Convention.

What conditions does the ECN set with regard to naturalisation? Article 6 (3) ECN obliges each state to provide for the possibility of naturalisation of persons lawfully and habitually residing within its territory. A State Party may not provide in its internal law, as a requirement for naturalisation, that an applicant must have resided in that country for more than 10 years before the application for naturalisation may be lodged. It is permitted, of course, to make naturalisation possible after a considerably shorter period of residence. The Convention does not prescribe that such residence must be lawful for the entire period.

On the basis of the first sentence of Article 6 (3), the only possible conclusion must be that the residence must be lawful at the moment of application. In the second sentence, which refers to the maximum period, the requirement of lawful residence is not repeated.

Article 6 (4) ECN contains a long list of persons, whose naturalisation must be facilitated. According to the explanatory report- facilitation includes 'a reduction of the length of required residence, less stringent language requirements, an easier procedure, lower procedural fees.'

The procedural provisions of Article $10 \mathrm{ff}$. are of particular importance for naturalisation procedures. Article 10 provides that each State Party must ensure that applications related to the acquisition, retention, loss, recovery or certification of its nationality are processed within reasonable time. The words 'within reasonable time' refer implicitly to the decisions of the European Court of Human Rights on the interpretation of Article 6 European Convention on Human Rights. Article 11 prescribes that the reasons for decisions relating to acquisition, retention, loss, recovery or certification must be included in the decision. This short provision is convincingly clarified in the explanatory report as follows:

'At a minimum, the legal and factual reasons need to be given. For decisions involving national security, only a minimum amount of information has to be provided. For decisions which were in accordance with the wishes or interests of the individual, for example the granting of the 
application, a simple notification or the issue of the relevant document will suffice.'

Article 12 of the Convention guarantees that decisions relating to acquisition, retention, loss, recovery or certification are open to administrative or judicial review in conformity with internal law. This general guarantee is remarkable, because in several countries decisions on naturalisation are made by statute without the possibility of judicial review. The explanatory report observes in that respect:

'It has been considered not to be appropriate in the present Convention to provide for an exception wherever decisions relating to naturalisations are taken by act of parliament and are not subject to appeal, as is the case in certain States. The general recognition of the right to appeal has indeed been estimated to be of prominent importance.'

The framers of the Convention were aware that high fees often impede access to a specific nationality or make it highly unattractive to renounce a particular nationality. Article 13 therefore prescribes that the fee for acquisition, retention, loss, recovery or certification must not be unreasonable. Furthermore, each State Party must ensure that the fees for administrative or judicial review do not form an obstacle.

In spite of these valuable rules the ECN, regrettably, lacks detailed provisions on the requirements for naturalisation. However, it must be pointed out that the Committee of Experts on Nationality that drafted the ECN, continues to have frequent meetings in Strasbourg and is working on recommendations and additional protocols. Its first product is Recommendation R (99) 18 of the Committee of Ministers to the Member States on the avoidance and reduction of statelessness. This recommendation deals inter alia with facilitating the naturalisation of stateless persons. More importantly, the Committee of Experts is presently working on a recommendation or protocol dealing with the requirements for naturalisation so as to achieve some degree of harmonisation. ${ }^{118}$ It would be more efficient, were the European Union to

118 Report on conditions for the acquisition and loss of nationality of 14 January 2003, prepared on the basis of a report of Andrew Walmsley. See in particular pp. 9-14. 
decide to participate in the preparatory work relating to recommendations and protocols to the ECN, in particular those documents dealing with naturalisation issues.

If there were a protocol to the ECN dealing with the requirements for naturalisation and the European Union managed to convince the Member States to ratify the Convention and its future protocols, the European Union itself would still need to undertake action in this respect: a Council of Europe treaty cannot provide that Member States take into account periods of residence in other Member States to meet residence requirements for naturalisation, nor that the requirement of residence in the country of application be waived, if the applicant recently moved to another Member State. ${ }^{119}$ These issues are intimately linked with the free movement guarantee under EU law and must therefore be regulated by the Union. The great advantage of cooperation between the European Union and the Council of Europe in the area of nationality law is that the Union may concentrate on the points just mentioned and leave the general attempts to harmonise this area of the law to the Council of Europe.

We are living in a fascinating age. State autonomy in matters of nationality, in particular within the European Union, is gradually weakening. There is no tendency, however, to abolish the nationalities of the Member States and replace them by European nationality or citizenship. There is, therefore, no movement towards a droit de nationalité européenne. What is emerging is a European law on nationality, a droit européen de nationalité. It remains to be seen whether this development will have serious consequences in the long term for the constitution or even statehood of the European Union.

119 The same holds true for the language requirements and the requirement of basic knowledge of the country's society and constitution. 


\section{Closing Remarks}

Je souhaiterais conclure cette conférence par deux remarques personelles.

Tout d'abord, je voudrais exprimer ma gratitude envers l'Université de Liège pour m'avoir permis de donner un cours de droit de la nationalité comparé en tant que professeur invité de la chaire Pierre Harmel. J'espère sincérement que ce cours sera une première étape vers une cooperation plus étroite entre l'Université de Liège et celle de Maastricht ainsi qu'entre nos deux facultés de droit.

Par ailleurs, je suis heureux de faire ce cours sur le droit de la nationalité comparé en Belgique. Je ne possède moi-même que la seule nationalité des Pays-Bas mais ma famille a des liens très étroits avec la Belgique. Ma mère a grandi en Belgique et y a vécu de 1920 à 1950.

Si une attitude plus positive de la Belgique et des Pays-Bas avait existé, il y a 50 ou 60 ans, à l'égard des cas de double nationalité, je possèderais certainement aussi la nationalité belge. Ce n'est pas le cas actuellement mais je vous assure que j'ai une profonde sympathie pour ce pays. 


\section{Bibliography}

Autem

Michel Autem, The European convention on nationality: is a European Code on nationality possible, in: 1st European conference on nationality, Trends and developments in national and international law on nationality, Strasbourg, Council of Europe, 18 and 19 October 1999, Proceedings, p. 19-34

Alvarez Rodríguez

Aurelia Alvarez Rodríguez, Modificacion del Convenio de doble nacionalidad entre España y Nicaragua, visited on http://www.reicaz.es/extranjeria/revista/001/ 01 003 htm (28 August 2000, no longer available in 2003)

Alvarez Rodríguez 2002

Aznar Sanchez

Bleckmann CMLR 1978

Albert Bleckmann, German nationality within the meaning of the EEC treaty, Common Market Law Review 1978, p. 435-446

Bleckmann CMLR 1980

Albert Bleckmann, The personal jurisdiction of the European Community, Common Market Law Review 1980, p. 467-485; also published in: Albert Bleckmann, Studien zum Europäischen Gemeinschaftsrecht, Köln: 1986, p. 373-392

Bonner ELR 1982

David Bonner, British citizenship: implications for United Kingdom nationals in the European Communities, European Law Review 1982, p. 69 ff.

Borras Rodriguez

Borras Rodriguez, Alegria, Comment on the Micheletti-decision of the ECJ, Revista Juridica de Catalunya 1993, p. 584-587 
Burgers-Vos

Carlier/Goflin

Carrascosa TINLP 1994

Castro Oliveira 1997

Closa CMLR 1992

Closa 1994

Closa CMLR 1995

Coppa

Curtin/Van Ooik
J.M. Burgers-Vos, Europa '92 en het vrije verkeer van en het vrije verkeer van werknemers, TAR Justicia 1992, p. 3-15

Jean Yves Carlier/ Sarah Goflin, 'Le droit belge de la nationalité', in Bruno Nascimbene (ed.), Nationality laws in the European Union, Milano etc.: Giuffrè/Butterworths 1996

Javier Carrascosa, Dual nationality and Community law: the Micheletti case, Tolleys Immigration and Nationality Law and Practice 1994, p. 7-12

Alvaro Castro Oliveira, The position of resident third-country nationals: Is it to early to grant them Union Citizenship?, in: Massimo La Torre (ed.), European citizenship: an institutional challenge, s-Gravenhage: Kluwer 1997, p. 207-223

Carlos Closa, The concept of citizenship in the Treaty on European Union, Common Market Law Review 1992, p. 1137-1169

Carlos Closa, Citizenship of the Union and Nationality of Member States, in: David OKeeffe /Patrick M. Twomey (ed.), Legal Issues of the Maastricht Treaty, London etc. (Chancery Law Publishing) 1994, p. 109-120

Carlos Closa, Citizenship of the Union and Nationality of Member States, Common Market Law Review 1995, p. 487-518

Gustavo R. Coppa, 'Los convenios de nacionalidad', paper presented at the "1ras Jornadas sobre el régimen jurídico de la nacionalidad argentina", Buenos Aires, 19/20 November 2002, available on http://www.cancilleria.gov.ar/jornada/programa.htm (last visited on 25 October 2003)

Deirdre M. Curtin/ Van Ooik, Denmark and the Edinburgh summit: Maastricht without tears, A legal analysis, in: David O'Keeffe/Patrick $M$. Twomey (ed.), Legal issues of the Maastricht Treaty, London 1994, p. 349-365. 
Espinar Vicente

Evans SLT 1981

Evans MLR 1982

Evans YEL 1982

Evans AJCL 1984

Evans ELR 1991

Evans/Jessurun d'Oliveira

Evans 1995

Evans, La Torre 1998

Greenwood YEL 1987
Jose Maria Espinar Vicente, La 'resolucion' de los conflitos de nacionalidad en el derecho comunitario, La Ley-Communidades Europeas 1994, nr. 84 , p. $1-5$

Andrew C. Evans, The new British nationality bill and European community law, Scots Law Times 1981, p. 133-137

Andrew C. Evans, European citizenship, Modern Law Review 1982, p. 497-515

Andrew C. Evans, Nationality law and the free movement of persons in the EEC, with special reference to the British Nationality Act 1981, Yearbook of European Law 1982, p. 174-189

Andrew C. Evans, European citizenship: a novel concept in EEC law, American Journal of Comparative Law 1984, p. 679-715

Andrew C. Evans, Nationality law and European integration, European Law Review 1991, p. 190-215

Andrew Evans/Hans-Ulrich Jessurun d'Oliveira, Nationality and Citizenship, in: Antonio Cassese /Andrew Clapham/Joseph Weiler (ed.), Human Rights and the European Community: Methods of Protection, Baden-Baden: Nomos Verlagsgesellschaft 1991

Andrew C. Evans, Union citizenship and the equality principle, in: A. Rosas/E. Antola (ed.), A citizens Europe. In search of a new order, Sage, Londen etc. 1995, p. 85-112

Andrew Evans, Union citizenship and the constitutionalisation of equality in EU law, in: Massimo La Torre (ed.), European citizenship: an institutional challenge, 's-Gravenhage: Kluwer Law International 1998, p. 267-293

Christopher Greenwood, Nationality and the Limits of the Free Movement of Persons in Community Law, Yearbook of European Law 1987, $185 \mathrm{ff}$. 
De Groot 1989

De Groot 1990

De Groot MR 1992

De Groot, Aruba 1993

De Groot, FS Bleckmann 1993

De Groot, La Torre 1998

De Groot MR 1998

De Groot, FJR 1998

De Groot AJ 1998
Gerard-René de Groot, Staatsangehörigkeitsrecht im Wandel, Köln etc.: Heymanns 1989

Gerard-René de Groot, Afbreken Berlijnse muur: gevolgen voor EEG-landen, Publiek Domein 1990, p. 2-6

Gerard-René de Groot, Noot onder de Michelettibeslissing van het Hof van Justitie van de Europese Gemeenschap, Migrantenrecht, Katern voor de Rechtspraktijk 1992, p. 105-110

Gerard-René de Groot, Aruba, de Europese Gemeenschap en het nationaliteitsrecht, in: G.F.M. Bossers/A.R.O. Ringeling/M. Tratnik (ed.), Cinco aña na caminda, Opstellen aangeboden ter gelegenheid van het eerste lustrum van de (Faculteit der Rechtsgeleerdheid van de) Universiteit van Aruba, Lustrumbundel Universiteit van Aruba, Oranjestad: 1993, p. 43-48

Gerard-René de Groot, Auf dem Weg zu einer europäischen Staatsangehörigkeit, in: Coen/ Hölscheidt/Pieper (ed.), Europa 1993, Auf dem Weg zur Europäischen Union, Festschrift für Albert Bleckmann, Berlin: 1993, p. 87-103

Gerard-René de Groot, The relationship between the nationality of the Member States of the European Union and European citizenship, in: Massimo La Torre (ed.), European citizenship: an institutional challenge, 's-Gravenhage: Kluwer Law International 1998, p. 115-147

Gerard-René de Groot, Negeert Spanje de Micheletti-beslissing van het Europese Hof van Justitie?, Migrantenrecht 1998, p. 117, 118

Gerard-René de Groot, Het Europese nationaliteitsverdrag: een nieuwe uitdaging voor het Nederlandse nationaliteitsrecht, FJR 1998, p. $234-241$

Gerard-René de Groot, Het Europese nationaliteitsverdrag: een bron van inspiratie voor de ontwikkeling van het Nederlandse nationaliteitsrecht, in: Aruba Juridica 1998-4, p. 28-49 
De Groot MJ 2000

De Groot MR 2000

De Groot 2001

De Groot, Acquisition 2002

De Groot MJ 2002
Gerard-René de Groot, The European Convention on Nationality: a step towards a ius commune in the field of nationality law, Maastricht Journal of European and Comparative Law 2000, p. 117-157

De Groot, Obywatelstwo 2000 Gerard-René de Groot, Obywatelstwo europejskie: zwiazki z obywatelstwem panstw czlonkowskich, Osrodek informacji Rady Europy, Centrum europejskie Uniwersytetu Warszawskiego, Biuletyn 4/5/200o, p. 7-36

Gerard-René de Groot, Visumplicht Antillianen /Arubanen en het Europese burgerschap, Migrantenrecht 2000, p. 51-52

Gerard-René de Groot, Europäische Bürgerschaft und die Staatsangehörigkeit der Mitgliedstaaten der Europäischen Union, in: Christian Bremen/Armin Heinen/Rüdiger Stotz (ed.), Die Europäische Union als Rechts- und Verfassungsraum. Zukünftige Aufgaben und Gegenwart, St. Augustin: Gardez Verlag 2001, p. 208-234

Gerard-René de Groot, Conditions for the acquisition of nationality by operation of law ex lege or by lodging a declaration of option. Report for the Second European conference on nationality: "Challenges to national and international law on nationality at the beginning of the new millenium", Council of Europe, Strasbourg 2001, p. 65-93; Conditions d'acquisition de la nationalité ex lege ou par déclaration d'option. Rapport pour la deuxième conférence européenne sur la nationalité: "Défis au droit national et international sur la nationalité à l'aube du nouveau millénaire", Counseil de l'Europe, Strasbourg 2001, p. 67-95; Updated version published as: Conditions for acquisition of nationality by operation of law or by lodging a declaration of option, Maastricht Journal of European and Comparative Law 2002, p. 121-160

Gerard-René de Groot, Het Europese Nationaliteitsverdrag in werking getreden voor Nederland, Migrantenrecht 2002, p. 4-12 
De Groot, Müller-Graf 2002

De Groot MJ 2002

De Groot, Loss 2003

De Groot, Handboek 2003

Guiguet 1997

Guiguet 1998
Gerard-René de Groot, Zum Verhältnis der Unionsbürgerschaft zu den Staatsangehörigkeiten in der Europäischen Union, in: Peter Christian Müller-Graf (ed.), Europäisches Integrationsrecht im Querschnitt, Baden-Baden: Nomos 2002, p. 67-86

Gerard-René de Groot, Latin-American European citizens: Some consequences of the autonomy of the Member States of the European Union in nationality matters, in: Maastricht Journal of European and Comparative law 2002, p. 115-120.

Gerard-René de Groot, The loss of nationality; a critical inventory, in: David.A.Martin / Kay Hailbronner. Rights and Duties of Dual Nationals: Evolution and Prospects, The Hague/ London /Boston: Kluwer Law International 2003, 201-299

Gerard-René de Groot, Handboek Nieuw Nederlands Nationaliteitsrecht, Deventer: Kluwer 2003

Benoît Guiguet, Citoyenneté et nationalité: Limites de la rupture d'un lien, dissertation, Florence: European University Institute 1997

Benoît Guiguet, Citizenship and nationality: tracing the French roots of the distinction, in: Massimo La Torre, European citizen ship, An institutional challenge, 's Gravenhage etc.: Kluwer Law International 1998, p. 95-111.

Hailbronner/Renner/KreuzerKay Hailbronner/Günter Renner/Christine Kreuzer, Staatsangehörigkeitsrecht, München: Beck 2001, p. $206-248$

Hall 1995

Stephen Hall, Nationality, Migration Rights and Citizenship of the Union, Dordrecht etc.: Martinus Nijhoff 1995

Hall ELR 1996

Stephen Hall, Loss of Union citizenship in breach of fundamental rights, European law review 1996, p. 129-143

Hansen/Weil

Randall Hansen/Patrick Weil, Towards a European nationality; Citizenship, immigration and nationality law in the EU, Houndmills: Palgrave 2001. 


\begin{abstract}
Hartley
Hofmann

Iglesias Buhigues

T.C. Hartley, EEC Immigration Law, Oxford: North Holland Publishing Company 1978

Rainer Hofmann, German citizenship law and European citizenship: Towards a special kind of dual nationality?, in: Massimo La Torre (ed.), European citizenship: an institutional challenge, 's-Gravenhage: Kluwer 1997, p. 165-184

Jose Luis Iglesias Buhigues, Doble nacionalidad y derecho comunitario: a propósito del asunto C 369/90, Micheletti, sentencia del TJCE de 7 de Julio de 1992, in: Hacia un nuevo orden internacional y europeo. Homenaje al profesor M. Diéz de Velasco, Madrid: Tecnos 1993, p. 953-967
\end{abstract}

Jessurun d'Oliveira 1994

Jessurun d'Oliveira 1995

Jessurun d'Oliveira, Trends

Jessurun d'Oliveira 1999

Juárez Pérez

Jessurun d'Oliveira, CMLR 1993 Hans Ulrich Jessurun d'Oliveira, Case-note (Case C-369/90, M.V. Micheletti and others v. Delegacion del Gobierno en Cantabria, Judgment of 7 July 1992), Common Market Law Review 1993, p. 623-637

Hans Ulrich Jessurun d'Oliveira, European citizenship: Its meaning, its potential, in: Renaud Dehousse (ed.), Europe after Maastricht: An ever close Union?, München: 1994, p. 126-148

Hans Ulrich Jessurun d'Oliveira, Union citizenship: Pie in the sky, in: A. Rosas \& E. Antola (ed.), A citizens Europe. In search of a new order, Londen etc.: Sage 1995, p. 58-84

Hans Ulrich Jessurun dOliveira (ed.), Trends in het nationaliteitsrecht, 's-Gravenhage: Sdu 1998

Hans Ulrich Jessurun d'Oliveira, Nationality and the European Union after Amsterdam, in: David OKeeffe/Patrick Twomey, Legal issues of the Amsterdam Treaty, Oxford: 1999, p. 395-412

Pilar Juárez Pérez, Nacionalidad estatal y ciudadanía europea, Madrid: Marcial Pons 1998 
Kojanec

Kotalakidis

Kreuzer

Martha

Kovar/Simon

Lippolis

Mortelmans/Temmink

O'Keeffe/Twomey

O'Keeffe 1994

O'Keeffe/Bavasso
G. Kojanec, The citizenship of the European Union, in: Aan de grenzen van het Nederlanderschap, Feestbundel voor F.Th. Zilverentant, Ministerie van Justitie - Directie Wetgeving, s-Gravenhage: 1998, p. 133-138

Nikolaos Kotalakidis, Von der nationalen Staatsangehörigkeit zur Unionsbürgerschaft, Die Person und das Gemeinwesen, Baden-Baden: Nomos Verlaggesellschaft 2000

Christine Kreuzer, Der Entwurf eines Übereinkommens des Europarates zu Fragen der Staatsangehörigkeit, StAZ 1997, p. 125-132

R.S.J. Martha, Antillianen, Arubanen en het vrije verkeer van werknemers in Europa, TAR Justicia 1992, p. 205-211

Kovar/ Simon, La citoyenneté européenne, CDE 1994, p. $299 \mathrm{ff}$.

Vincenzo Lippolis, La cittadinanza europea, Bologna (II Mulino): 1994

K.J.M. Mortelmans/ H.A.G. Temmink, Het vrije personenverkeer tussen de Nederlandse Antillen en Aruba en de Europese Gemeenschap, in: Met het oog op Europa: De Europese Gemeenschap, De Nederlandse Antillen en Aruba, Justicia 1991, p. 51-91

David O'Keeffe \& Patrick M. Twomey (ed.), Legal Issues of the Maastricht Treaty, London etc.: Chancery Law Publishing 1994, p. 87-108

David O'Keeffe, Citizenship of the Union, Actualités du droit 1994, p. 227-248

David O'Keeffe/Antonio Bavasso, Fundamental rights and the European Union, in Massimo la Torre (ed.), European citizenship; An Institutional Challenge, 's Gravenhage: Kluwer Law International 1998 p. 251-266 
O'Leary YEL 1992

O'Leary CMLR 1995

O'Leary 1993

Nascimbene

Pérez Vera RIE 1981

Pérez Vera 1993

Plender

Preuss

Ruzié
Siofra O'Leary, Nationality Law and Community Citizenship: A Tale of Two Uneasy Bedfellows, Yearbook of European Law 1992, p. $353 \mathrm{ff}$.

Siofra O'Leary, The relationship between Community citizenship and the protection of fundamental rights in community law, Common Market Law Review 1995, p. 519-554

Siofra O'Leary, The evolving concept of European citizenship. From the free movement of persons to Union citizenship, (diss. European University Institute). Firenze: 1993.

Bruno Nascimbene (ed.), Nationality laws in the European Union, Milano etc.: Giuffrè/ Butterworths 1996

Elisa Pérez Vera, El sistema español de doble nacionalidad ante la futura adhesión de España a las Comunidades Europeas, Revista de institutiones Europeas 1981, p. 685-703.

Elisa Pérez Vera, La ciudadanía en el tratado de Maastricht, in: Hacia un nuevo orden internacional y europeo. Homenaje al professor Don Manuel Díez De Veleasco, Madrid: Tecnos 1993, p. 1123-1147

Richard Plender, An incipient form of European citizenship, in: Francis Geoffrey Jacobs (ed.), European law and the individual, Amsterdam/ New York/Oxford 1976

U.K. Preuss, Problems of a concept of European citizenship, European law journal 1995, p. 267-281

David Ruzié, Nationalité, effectivité en droit communautaire, Revue generale de droit international public 1993, p. 107-120 
Sabourin

Sauerwald

Sebastien

Saura Estapa

Schade

Simmonds

La Torre

Verwilghen

Vink

Vrinds
Norman Sabourin, The relevance of the European convention on nationality for non-European states, in: 1st European conference on nationality, Trends and developments in national and international law on nationality, Strasbourg, Council of Europe, 18 and 19 October 1999, Proceedings, p. $113-123$

Christine Sauerwald, Die Unionsbürgerschaft und das Staatsangehörigkeitsrecht in den Mitglied-staaten der Europäischen Union, Berlin: 1996

G. Sebastien, La citoyenneté de I'Union européenne, RDP 1993, p. 1263-1289

Jaume Saura Estapa, Nacionalidad y nuevas fronteras en Europa, Madrid: Marcial Pons 1998

Horst Schade, The Draft European Convention on Nationality, Austrian Journal of Public and International Law 1995, p. 99-103

Kenneth R. Simmonds, The British Nationality Act and the definition of the term national for Community purposes, Common Market Law Review 1984, p. 675-686

Massimo La Torre (ed.), European citizenship: an institutional challenge, 's-Gravenhage: Kluwer 1997

Michel Verwilghen, Conflit de nationalités: Plurinationalité et apatridie, Recueil des cours de I'Académie de droit international, tome 277, The Hague etc.: Martinus Nijhoff 1999

Maarten P. Vink, Limits of European citizenship, European integration and immigration policies in the Netherlands, diss., (University of Leyden, 2003)

Erik P.J. Vrinds, Die Reform des niederländischen Staats-angehörigkeitsrechts, StAZ 2004, p. 1-9 
Walmsley

Weil

Zilverentant
Andrew Walmsley, The acquisition of nationality through naturalisation. An assessment of European legislation. Report for the Second European conference on nationality: "Challenges to national and international law on nationality at the beginning of the new millenium", Council of Europe, Strasbourg 2001, p. 95-107

Patrick Weil, Access to citizenship: a comparison of twenty-five nationality laws, in: T. Alexander Aleinikoff/ Douglas Klusmeyer (eds.), Citizenship Today: global perspectives and practices, Washington D.C.: Carnegie Endowment for International Peace, p. 17-35

F.Th. Zilverentant, Bericht uit Straatsburg, in: H.U. Jessurun d'Oliveira, Trends in het nationaliteitsrecht, Nationaal en internationaal, 's-Gravenhage: Sdu 1998, p. 49-52 


\section{List of abbreviations:}

$\begin{array}{ll}\text { AJ } & \text { Aruba juridica } \\ \text { ACJL } & \text { American Journal of Comparative Law } \\ \text { art. } & \text { Article } \\ \text { BGBI } & \text { Bundesgesetzblatt } \\ \text { BOE } & \text { Boletin Oficial del Estado } \\ \text { BNA } & \text { British Nationality Act } \\ \text { C } & \text { Case } \\ \text { CDE } & \text { Cahiers de Droit Européen } \\ \text { CMLR } & \text { Common Market Law Review } \\ \text { Diss. } & \text { Dissertation (Doctorate thesis) } \\ \text { Doc. Parl. } & \text { Documentation Parlementaire } \\ \text { EC } & \text { European Community } \\ \text { ECJ } & \text { European Court of Justice } \\ \text { ECN } & \text { European Convention on Nationality } \\ \text { ECR } & \text { European Court Reports } \\ \text { ECT } & \text { European Community Treaty } \\ \text { Ed. } & \text { editor } \\ \text { EEC } & \text { European Economic Community } \\ \text { EESC } & \text { European Economic and Social Committee } \\ \text { e.g. } & \text { for example } \\ \text { ELR } & \text { European Law Review } \\ \text { etc. } & \text { et cetera } \\ \text { ETS } & \text { European Treaties Series } \\ \text { EU } & \text { European Union } \\ \text { ff. } & \text { and following } \\ \text { FJR } & \text { Tijdschrift voor Familie- en Jeugdrecht } \\ \text { G.U. } & \text { Gazetta Ufficiale } \\ \text { MJ } & \text { Maastricht Journal of European and Comparative Law } \\ \text { MLR } & \text { Modern law Review } \\ \text { MR } & \text { Migrantenrecht } \\ \text { nr. } & \text { Number } \\ \text { O.C. } & \text { opere citato } \\ \text { OJ } & \text { Official Journal } \\ \text { p. } & \text { page } \\ \text { par. } & \text { Paragraph } \\ \text { RDP } & \text { Revue de Droit Privé } \\ \text { RIE } & \text { Revista de Institutiones Europeas } \\ \text { Sect. } & \text { section } \\ \end{array}$


SLT Scots Law Times

StAZ Zeitschrift für das Standesamtswesen

stat. statutes

TINLP Tolleys Immigration and Nationality Law and Practice

U.K. United Kingdom

USC United States Consolidated Statutes

YEL Yearbook of European Law 
